\title{
Update on vaccine development for renal cell cancer
}

This article was published in the following Dove Press journal:

Open Access Journal of Urology

29 July 2010

Number of times this article has been viewed

\author{
Nina Chi ${ }^{\prime}$ \\ Jodi K Maranchie ${ }^{2,3}$ \\ Leonard J Appleman ${ }^{3,4}$ \\ Walter J Storkus ${ }^{1,3,5}$ \\ 'Department of Immunology, \\ University of Pittsburgh School \\ of Medicine, Pittsburgh, Pennsylvania, \\ United States; ${ }^{2}$ Department \\ of Urology, University of Pittsburgh \\ School of Medicine, Pittsburgh, \\ Pennsylvania, United States; \\ ${ }^{3}$ University of Pittsburgh Cancer \\ Institute, Pittsburgh, Pennsylvania, \\ United States; ${ }^{4}$ Department of \\ Medicine, University of Pittsburgh \\ School of Medicine, Pittsburgh, \\ Pennsylvania, United States; \\ ${ }^{5}$ Department of Dermatology, \\ University of Pittsburgh School of \\ Medicine, Pittsburgh, Pennsylvania, \\ USA
}

Correspondence:Walter J Storkus Department of Dermatology and Immunology,WI04I.2 BST, 200 Lothrop Street, Pittsburgh, PA I5213, USA

Tel $+|-4| 2-648-998 \mid$

Fax + I-4I2-383-5857

Email storkuswj@upmc.edu

\begin{abstract}
Renal cell carcinoma (RCC) remains a significant health concern that frequently presents as metastatic disease at the time of initial diagnosis. Current first-line therapeutics for the advanced-stage RCC include antiangiogenic drugs that have yielded high rates of objective clinical response; however, these tend to be transient in nature, with many patients becoming refractory to chronic treatment with these agents. Adjuvant immunotherapies remain viable candidates to sustain disease-free and overall patient survival. In particular, vaccines designed to optimize the activation, maintenance, and recruitment of specific immunity within or into the tumor site continue to evolve. Based on the integration of increasingly refined immunomonitoring systems in both translational models and clinical trials, allowing for the improved understanding of treatment mechanism(s) of action, further refined (combinational) vaccine protocols are currently being developed and evaluated. This review provides a brief history of RCC vaccine development, discusses the successes and limitations in such approaches, and provides a rationale for developing combinational vaccine approaches that may provide improved clinical benefits to patients with RCC.
\end{abstract}

Keywords: renal cell carcinoma, vaccines, immunotherapy, combinational therapy, cellular immunity

\section{Introduction: immunotherapy for renal cell carcinoma}

Renal cell carcinoma (RCC) accounts for approximately 3\% of all cancers in adults, with metastases identified in $20 \%-30 \%$ of patients at the time of diagnosis. Metastatic $\mathrm{RCC}$, if left untreated, has a 5-year disease-free survival rate of $2 \%-11 \% .{ }^{1}$ Following nephrectomy, conventional treatments with standard chemotherapeutic agents, hormones, and radiotherapy have shown minimal success. This has prompted extensive evaluation of alternate treatment strategies, including immunotherapies, in the adjuvant and advanced disease settings.

Optimism for the use of biological response modifiers and vaccines has been buoyed by past findings, which suggest that, like melanoma, RCC progression and regression may be regulated by immunologic mechanisms. ${ }^{2-5}$ Patients with RCC exhibited a low but significant incidence of spontaneous regression, ${ }^{6,7}$ and patients under chronic immunosuppression regimens to retain kidney allografts displayed an increased risk of developing RCC. ${ }^{8}$ The degree of tumor infiltration by lymphocytes has been used as a prognostic indicator for patient survival. ${ }^{9,10}$ In particular, T cells of the type-1 polarization profile (ie, capable of producing interferon [IFN]- $\gamma$ and mediating the cytotoxic death of RCC tumor cells) and proliferative potential ${ }^{11,12}$ have proven

submit your manuscript $\mid$ www.dovepress.com 
to represent primary immunologic mediators of objective clinical responses (OCRs).

However, patients with RCC are frequently characterized with a state of "immune dysfunction", ${ }^{13-16}$ where type-1 responses directed against tumor-associated antigens are muted in comparison with type-2 (normally associated with antibody production and allergic reactivity) and/or T-regulatory (Treg) responses, which are immunosuppressive in nature. ${ }^{17-20}$ Furthermore, when the responses can be identified, type- 1 anti-RCC T cells may be proapoptotic under a chronic state of stimulation with specific tumor antigens in patients with cancer. ${ }^{21,22}$

\section{Rationale for RCC vaccines}

As depicted in Figure 1, therapeutic normalization of type-1, antitumor T-cell-mediated immunity in patients with RCC requires one or more of the following processes to occur: (1) existing tumor antigen-experienced $\mathrm{T}$ cells exhibiting anergy or nontype-1 functional polarization need to be reactivated or retrained to become type-1 polarized; (2) the survival and functionality of existing type-1 $\mathrm{T}$ cells must be extended; (3) new type-1 effector cells must be "primed" from the naive cohort of T cells (a process that may require the "breaking" of operational tolerance); (4) effective trafficking of renal cell carcinoma - associated antigen (RCCAA)-specific T cells to the tumor microenvironment (TME); and/or (5) blunting of regulatory T cells (Treg) that suppress effector T-cell activation, function, and durability. Each of these immunologic end points may be theoretically achieved via the implementation of tumor-specific vaccines that contain and/or condition antigen-presenting cells (APCs) in situ to assume type-1 function (typically associated with the ability of APCs to differentially secrete interleukin [IL]-12 vs IL-10). ${ }^{23-25}$ Reports have shown that type-2 "memory" T-cell responses (ie, characterized by strong IL-4 and IL-5 production) may be repolarized toward type-1 immunity in vitro by (re)stimulation with antigenpulsed dendritic cells (DCs) that were preconditioned with proinflammatory cytokines, toll-receptor ligands, and other costimulatory adjuvants. ${ }^{23,26,27}$ In humans, type-1 effector $\mathrm{T}$ cells have exhibited extended survival, function, and conversion into the memory cells when provided signals

\section{RCC-Induced immune deviation (Pre-vaccine)}

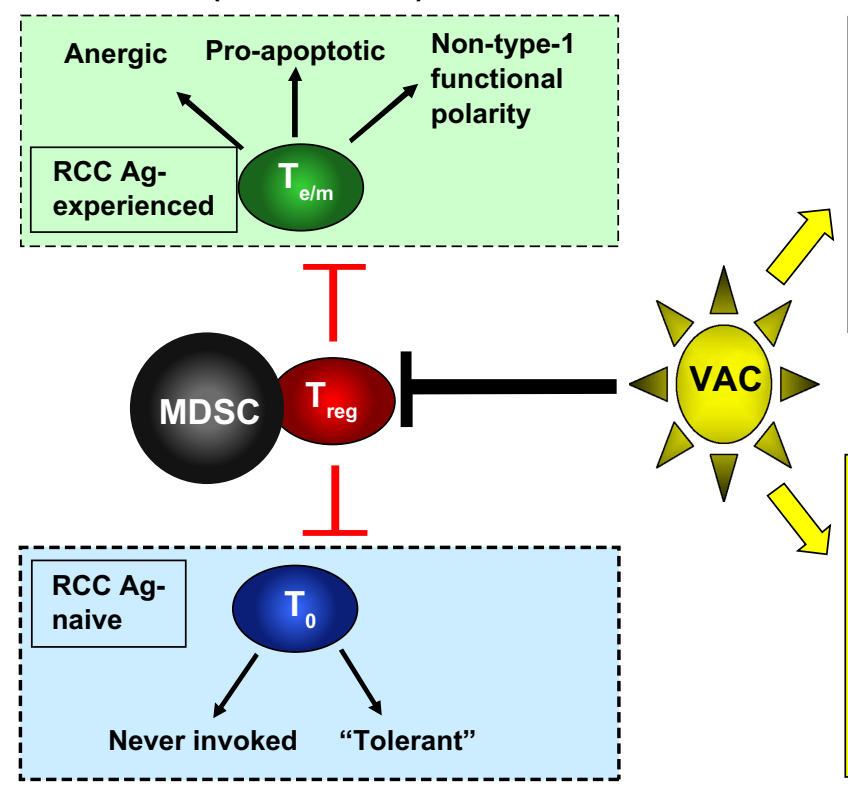

\section{Preferred immunologic outcomes (Post-vaccine)}
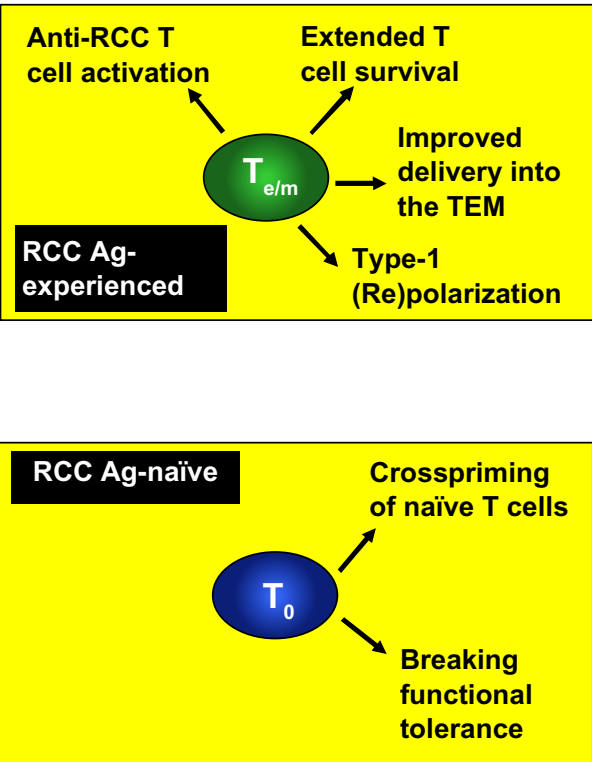

Figure I Paradigm for effective renal cell carcinoma (RCC) vaccines. Antitumor T cells in patients with RCC are frequently anergic, hyporesponsive, or they may mediate functions that are nonprotective. $T$ effector $\left(T_{e}\right)$ and memory $\left(T_{m}\right)$ cells (cumulatively indicated as $T_{e / m}$ ) may also be prone to apoptotic death based on conditioning by tumor cells or their elaborated products in vivo. Naive $\left(T_{0}\right)$ antitumor T cells may be rendered nonresponsive or exhibit specificities against "subdominant" RCC-associated antigens (RCCAAs) or epitopes that have failed to become activated productively. Furthermore, the vitality and function of antitumor $T$ cells may be inhibited by regulatory $\mathrm{T}$ cells and myeloid-derived suppressor cells (MDSCs), particularly in the tumor microenvironment (TME). Effective vaccine formulations would at least partially correct such defects by (re)activating $\mathrm{T}_{\mathrm{e} / \mathrm{m}}$ and promoting their extended survival and delivery into the TME. Importantly, given some plasticity in functional T-cell polarization, effective RCC vaccines may promote a conversion of nontype-I T-cell responses towards type-I immunity, which has been commonly associated with improved clinical prognosis. Such vaccine-induced repolarization in T-cell function may foster the breaking of operational tolerance against additional RCCAAs and the cross-priming of a broadly reactive antitumor T-cell repertoire. If sustained (through booster vaccination), this vaccine-initiated T-cell response may extend time to disease recurrence or progression and overall patient survival. 
from $\mathrm{CD} 16^{+}$monocyte-derived DCs. ${ }^{28}$ Furthermore, type- 1 polarized or conditioned DCs appear superior to alternate APC types in their capacity to activate and drive naive T-cell differentiation into type-1 $\mathrm{CD} 4^{+}$and $\mathrm{CD} 8^{+} \mathrm{T}$ effector cells in vitro and in vivo. ${ }^{23,29,30}$ Although much of these data have been developed translationally in the context of cell (ie, DC-based) therapeutics, it would also be predicted that cellfree vaccine formulations including the appropriate tumor antigens and conditioning adjuvants would activate APC in situ with similar type-1-polarizing potential. ${ }^{31-33}$

\section{RCCAA and vaccine construction}

Vaccines designed to promote specific adaptive immunity against RCC have been traditionally grouped into 4 general categories. One type of tumor vaccine is RCC cells themselves (either autologous or allogenic cells that express unique and shared tumor-associated antigenic proteins). More than 20 years ago, Miller et $\mathrm{al}^{34}$ trialed autologous RCC tumor cells using Cryptosporidium parvum as an adjuvant. Later, Tani et $\mathrm{al}^{35}$ and others modified the autologous tumor cell vaccine by using granulocyte macrophage-colony-stimulating factor (GM-CSF) or other inflammatory cytokines as adjuvant. Thereafter, others used genetically modified patient tumor cells that expressed inflammatory cytokines, including GM-CSF, IFN- $\gamma$, and IL-2. ${ }^{36}$ Another tumor vaccine formulation is represented by RCC-APC fusion hybrids, which generate APCs that are capable of expressing RCC gene products and presenting their derivative peptide epitopes to $\mathrm{T}$ cells. Avigan et $\mathrm{al}^{37}$ were one of the few groups that used this strategy to treat patients with RCC. They fused autologous tumor cells to DCs from normal donors using serial electrical pulses. Another approach involves RCC-derived total mRNA or cDNA (encoding the complete repertoire of RCCAA). Although most published work using these vaccines has been limited to preclinical models, ${ }^{38,39} \mathrm{Su}$ et $\mathrm{al}^{40}$ used autologous DCs transfected with total RCC RNA. More recently, several laboratories have been moving toward a more specified vaccine formulation using peptides, protein, mRNA, or cDNA derived from or encoding one or more molecularly defined RCCAAs (Table 1 ). Wierecky et $\mathrm{al}^{41}$ and Bleumer et $\mathrm{al}^{42}$ have vaccinated $\mathrm{RCC}$ patients with mucin (MUC1) and carbonic anhydrase (CA-IX) peptides, respectively, loaded on to autologous DCs. The clinical outcomes associated with these various vaccine formulations will be discussed later in this review.

A myriad of genetic aberrations can potentially develop within the evolving heterogeneous RCC lesion over many months to years under immune selective pressure. The first
3 categories of vaccines cited earlier theoretically provide the greatest variety of RCCAAs, which promote the broadest antitumor T-cell repertoire, when applied in the context of a vaccine. In vaccines based on whole tumor cells, tumor-APC hybrids, and/or tumor-derived mRNA or cDNA, RCCAAs derived from mutant proteins with alternate open reading frames (ORFs), antisense transcripts, or unique proteinsplicing events (Table 1) will be incorporated without knowing the identity of the RCCAA. However, these approaches have limitations from an immunologic perspective. Complex mixtures of unknown RCCAA may merely reinforce an existing, yet failing, immune repertoire given the immune dominance of certain RCCAAs over others. Competition by hundreds or thousands of peptide epitopes for loading into major histocompatibility complex (MHC) molecules expressed by (cross-presenting) APCs in vivo could prevent attaining immunogenic quantities of RCCAA peptides. These types of vaccines would also introduce an array of immunsuppressive genes and gene products (ie, IL-10, transforming growth factor [TGF]- $\beta, \mathrm{B} 7-\mathrm{H} 1$, indoleamine 2,3-dioxygenase [IDO], etc) into the vaccine site that may negate the immunostimulatory potential of the treatment.

A less-dynamic, but better-controlled, vaccine approach involves the use of molecularly defined RCCAAs identified by tumor cell or tumor "genome-" or "proteome-based" approaches. Such a formulation reduces the effects of confounding immunosuppressive signals or competing ligands for $\mathrm{MHC}$ presentation. Among the many RCCAAs identified and defined as targets for T-cell recognition over the past 10-15 years, most of these gene products represent proteins that are 1) nonmutated, 2) frequently overexpressed by tumor vs normal kidney tissue, and 3) upregulated as a consequence of the hypoxic or hypomethylating conditions prevalent in the TME (Table 1). The conditional and/or preferential (over)expression allows for the differential expression of antigenic peptides in MHC complexes expressed by tumor cells vs normal cells. This property of RCCAAs encourages the development of therapeutic vaccines capable of eliciting antigen-specific $\mathrm{T}$ effector cells that may strategically eradicate tumor cells without manifesting pathologic autoimmune correlates.

Several well-defined RCCAAs have been (or could be) implemented in phase I/II vaccine trials for patients with RCC. A partial list of more than 30 such candidates is provided in Table 1 . Nearly 2 dozens of these gene products were reported to be (over) expressed in the majority of RCC specimens evaluated, making them tenable candidates for inclusion in a "general" vaccine for treating patients with 
Table I RCC-associated antigens (RCCAAs) recognized by T cells

\begin{tabular}{|c|c|c|c|c|c|}
\hline Antigen & $\begin{array}{l}\text { Antigen } \\
\text { category }\end{array}$ & $\begin{array}{l}\text { Frequency of } \\
\text { expression among } \\
\text { RCC tumors (\%) }\end{array}$ & $\begin{array}{l}\text { CD8 }{ }^{+} \text {T-cell recognition: } \\
\text { patients with HLA class I } \\
\text { allele(s) }\end{array}$ & $\begin{array}{l}\mathrm{CD4}^{+} \mathrm{T} \text {-cell recognition: } \\
\text { patients with HLA class II } \\
\text { allele(s) }\end{array}$ & References \\
\hline Survivin ${ }^{\mathrm{a}}$ & $M L$ & 100 & Multiple & Multiple & 114 \\
\hline OFA-iLR & OF & 100 & $\mathrm{~A} 2$ & NR & 115,116 \\
\hline IGFBP3 $3^{\mathrm{a}, \mathrm{b}}$ & $M L$ & 97 & NR & Multiple & 117,118 \\
\hline $\mathrm{EphA} 2^{\mathrm{a}}$ & $M L$ & $>90$ & $\mathrm{~A} 2$ & DR4 & $17,44,119$ \\
\hline RU2AS & $\begin{array}{l}\text { Antisense } \\
\text { transcript }\end{array}$ & $>90$ & B7 & NR & 120 \\
\hline G250 (CA-IX) & $\mathrm{RCC}$ & 90 & $\mathrm{~A} 2, \mathrm{~A} 24$ & Multiple & 47,51 \\
\hline$E_{G F R^{a, b}}$ & $M L$ & 85 & $\mathrm{~A} 2$ & NR & 121,122 \\
\hline $\mathrm{HIFPH}^{\mathrm{a}}$ & $M L$ & 85 & $\mathrm{~A} 24$ & NR & 123 \\
\hline$c-M_{e t}{ }^{a}$ & $M L$ & $>80$ & $\mathrm{~A} 2$ & NR & 124 \\
\hline WT- $I^{a}$ & $M L$ & 80 & $\mathrm{~A} 2, \mathrm{~A} 24$ & NR & $125-128$ \\
\hline $\mathrm{MUCl}^{\mathrm{a}, \mathrm{b}}$ & $M L$ & 76 & $\mathrm{~A} 2$ & DR3 & $46,129,130$ \\
\hline $5 T 4$ & $M L$ & 75 & $\mathrm{~A} 2, \mathrm{Cw} 7$ & DR4 & $54,131-133$ \\
\hline $\mathrm{iCE}$ & $\mathrm{aORF}$ & 75 & B7 & NR & 134 \\
\hline$M M P 7^{a}$ & $M L$ & 75 & $\mathrm{~A} 3$ & Multiple & $117,135,136$ \\
\hline Cyclin DI & $M L$ & 75 & $\mathrm{~A} 2$ & Multiple & $117,137,138$ \\
\hline $\mathrm{HAGE}^{\mathrm{b}}$ & CT & 75 & $\mathrm{~A} 2$ & DR4 & 139 \\
\hline hTERT ${ }^{\mathrm{a}, \mathrm{b}}$ & $M L$ & $>70$ & Multiple & Multiple & $|40-| 42$ \\
\hline FGF-5 & $\begin{array}{l}\text { Protein splice } \\
\text { variant }\end{array}$ & $>60$ & $\mathrm{~A} 3$ & NR & 143 \\
\hline mutVHL & $M L$ & $>60$ & $N R$ & NR & 144 \\
\hline MAGE-A $3^{b}$ & CT & 60 & Multiple & Multiple & 145 \\
\hline SART-3 & $M L$ & 57 & Mulitple & NR & $146-149$ \\
\hline SART-2 & $M L$ & 56 & $\mathrm{~A} 24$ & NR & 150 \\
\hline PRAME $^{b}$ & CT & 40 & Multiple & $N R$ & $15 \mid-154$ \\
\hline$p 53^{a, b}$ & Mutant/WT ML & 32 & Multiple & Multiple & 155,156 \\
\hline MAGE-A9' & CT & $>30$ & $\mathrm{~A} 2$ & NR & 157 \\
\hline MAGE-A $6^{\mathrm{b}}$ & CT & 30 & Multiple & DR4 & 18,158 \\
\hline MAGE-D4 ${ }^{b}$ & CT & 30 & $\mathrm{~A} 25$ & NR & 159 \\
\hline Her $2 /$ neu $^{a}$ & $M L$ & $10-30$ & Multiple & Multiple & $45,160-164$ \\
\hline SART-I ${ }^{a}$ & $M L$ & 25 & Multiple & NR & $165-167$ \\
\hline RAGE-I & CT (ORF2/5) & 21 & Multiple & Multiple & $\begin{array}{l}151,157 \\
168,169\end{array}$ \\
\hline TRP-I/gP75 & $M L$ & 11 & $\mathrm{~A} 3 \mathrm{I}$ & DR4 & $15|| 70-172$, \\
\hline
\end{tabular}

Note: A summary is provided for RCCAAs that have been defined at the molecular level. RCCAAs are characterized with regard to their antigen category, their prevalence of (over) expression among total RCC specimens evaluated, whether RCCAA expression is modulated by hypoxia or tumor DNA methylation status, and which HLA class I and class II alleles have been reported to serve as presenting molecules for T-cell recognition of peptides derived from a given RCCAA. ${ }^{\mathrm{H}} \mathrm{H}$ poxia-induced. ${ }^{\mathrm{b}} \mathrm{Hypomethylation-}$ induced.

Abbreviations: CT, cancer-testis antigens; ML, multilineage antigens; NR, not reported; OF, oncofetal antigen; aORF, altered open reading frame; ORF, open reading frame; RCC, renal cell carcinoma; WT, wild type.

RCC. Notably, those RCCAAs that may function as general RCCAAs for use in vaccines include survivin, an inhibitor of apoptosis whose expression is correlated with poorly differentiated, advanced-stage $\mathrm{RCC} ;{ }^{43}$ the receptor tyrosine kinases (RTKs) EphA2, epidermal growth factor receptor (EGFR), c-Met, and Her2/neu; ${ }^{44,45}$ MUC1; ${ }^{46}$ CA-IX, also known as $\mathrm{G} 250 ;{ }^{47}$ and the oncofetal antigen $5 \mathrm{~T} 4{ }^{48}$

Of the aforementioned RCCAAs, CA-IX and 5T4 are 2 of the more frequently overexpressed RCC markers. CA-IX overexpression in RCC is associated with a defect in the Von Hippel-Lindau (VHL) tumor suppressor gene via activation of hypoxia-inducible factor- $\alpha$ (HIF- $\alpha) .{ }^{49}$ In conjunction with regulation by VHL-HIF, CA-IX expression is also driven by the methylation status of the $\mathrm{C} 9$ gene, as the $\mathrm{C} 9$ promoter has been reported to be hypomethylated in all CA-IX+ $\mathrm{RCC}$ cell lines and to be hypermethylated in all CA-IX- $\mathrm{RCC}$ cell lines. $.^{50} \mathrm{CA}-\mathrm{IX}$ is beginning to be exploited as a therapeutic target for RCC only now. ${ }^{51}$ Only within the last few years has an appropriate animal model been established to study CA-IX-expressing tumors, using human CA-IX-transduced murine RCC cells. ${ }^{52}$ Recently Bauer et al ${ }^{53}$ published promising results on a $\mathrm{G} 250$ - tumor necrosis factor fusion antibody administered with IFN- $\gamma$ to RCC xenograft-bearing nude mice; however, no CA-IX-based therapies have yet made it to 
clinic. The heavily glycosylated transmembrane protein 5T4 is overexpressed by RCC tumor cells. ${ }^{54}$ In a phase II trial for $\mathrm{RCC}$, a recombinant fusion protein composed of a modified form of staphylococcal enterotoxin A (SEA) linked to mouse Fab specific for 5T4 has exhibited antitumor efficacy, albeit in the context of moderate toxicity. ${ }^{55}$ Therapeutic viral vectors have also been used as a vaccination strategy, one being TroVax, a highly attenuated vaccinia virus, modified vaccinia ankara (MVA), which encodes the human 5T4 antigen. In a phase II trial, TroVax with IL-2 appeared to confer some clinical advantage, with some patients showing disease stabilization and an improved ratio of $\mathrm{CD}^{+}$effectors to Treg cells. ${ }^{56,57}$ Patients cotreated with TroVax and IFN- $\alpha$, however, did not show significant clinical improvement, despite having 5T4-specific antibody and/or cellular responses. ${ }^{58,59}$

In most cases, RCCAA-derived peptide epitopes recognized by $\mathrm{CD}^{+}$and/or $\mathrm{CD}^{+} \mathrm{T}$ cells have been identified. Such peptides may be used in vaccines for treating patients with relevant human leukocyte antigen (HLA) class I or II tissue types, which are required for presenting a given peptide epitope to the immune system. Recently, Rahma et $\mathrm{al}^{33}$ published results from a pilot study testing a mutant VHL peptide vaccine customized to each patient's specific mutation and HLA haplotypes, with $80 \%$ of the treated patients exhibiting specific immune responses. In Table 1, we list the HLA allelic molecules to which known RCCAA peptides bind and are recognized by $\mathrm{CD} 4^{+}$and $\mathrm{CD} 8^{+} \mathrm{T}$ cells. These peptides are also applicable in immune monitoring of specific in vitro T-cell responses of patients being treated with any form of vaccine or immunotherapy. Vaccination against a single peptide can potentially promote "epitope spreading" in the evolving antitumor $\mathrm{CD} 8^{+} \mathrm{T}$-cell repertoire based on cyclic and longitudinal cross-priming events within (tumor-draining) lymph nodes. ${ }^{41,60,61}$ Additionally, several peptides (from one or more RCCAAs) can be constructed into a single vaccine formulation using mixtures of peptides or an extended "bead-on-a-string" protein construct in which multiple epitopes are expressed in tandem. ${ }^{62-64}$ Such formulations focus the $\mathrm{T}$ cell on a more limited, but potentially more effective, cohort of RCCAA epitopes that may be immunologically subdominant and/or ignored under standard conditions, thereby unveiling a previously undertapped population of antitumor effector cells.

\section{RCC vaccines in the clinic}

Most of the clinical vaccine trials in patients with RCC performed till date have involved the use of whole tumor cells, tumor lysates, or the fusion of RCC cells with DCs. ${ }^{65,66}$
Vaccine formulations based on specific RCCAAs (protein, cDNA) or their derivative (MHC-presented) peptides have lagged behind due to the comparatively recent molecular identification of the applied RCCAA. Rather than providing a traditional tabulated summary of the data resulting from such trials, we provide a schematic diagram of trial outcomes based on the clinical (primary) and immunologic (secondary) end points defined in these protocols (Figure 2). We have further delineated vaccines based on the type of RCCAA utilized in each trial.

Despite recent discussions stating that immunotherapies should not be evaluated based on the "acute" response criteria (Response Evaluation Criteria in Solid Tumor [RECIST]) defined for chemotherapeutic agents because immunotherapies may depend on the gradual build up of adaptive immunity over a protracted period of time, ${ }^{67,68}$ virtually all reported RCC vaccine trials have still done so. Hence, in Figure 2, we have depicted OCR frequencies based on partial responses (PRs), complete responses (CRs), or stabilization of disease (SD) per RECIST criteria as reported by the primary investigators. The consensus of such information suggests that current RCC vaccines are generally safe and well tolerated, ${ }^{69}$ but are curative in only a very minor subset of treated patients. Although PRs increase in frequency somewhat after vaccine treatment, the major benefit of these cancer vaccines is reflected in many patients who exhibit stable disease, leading to increased progression-free and overall survival when compared with control groups. ${ }^{69-72}$ Notably, each of the various vaccine formulation categories listed yielded similar clinical impact based on RECIST criteria (Figure 2), with roughly $50 \%$ of treated patients exhibiting stable disease, $20 \%$ showing partial response, and $<20 \%$ developing CRs.

Since these represent immunotherapies rather than chemo- or radiotherapies, immunologic end point analyses are critical for determining the biological efficacy of these approaches and how such strategies may be improved based on our current understanding of RCC immunobiology. In this regard, the diverse array of RCC vaccine trials performed over the past 15 years has implemented a number of immune assessment assays to determine specific immune response to active vaccination, including analyses of patient tumorspecific T-cell responses in vitro (TRIV) and delayed-type hypersensitivity (DTH) responses to vaccine components in vivo. Assays for TRIV have dramatically evolved over the past decade, with established proliferation (ie, ${ }^{3} \mathrm{H}$-thymidine incorporation) and cytokine (ie, enzyme-linked immunosorbent assay [ELISA]) assays now being supplanted by methods capable of discerning the frequency and/or functionality of 


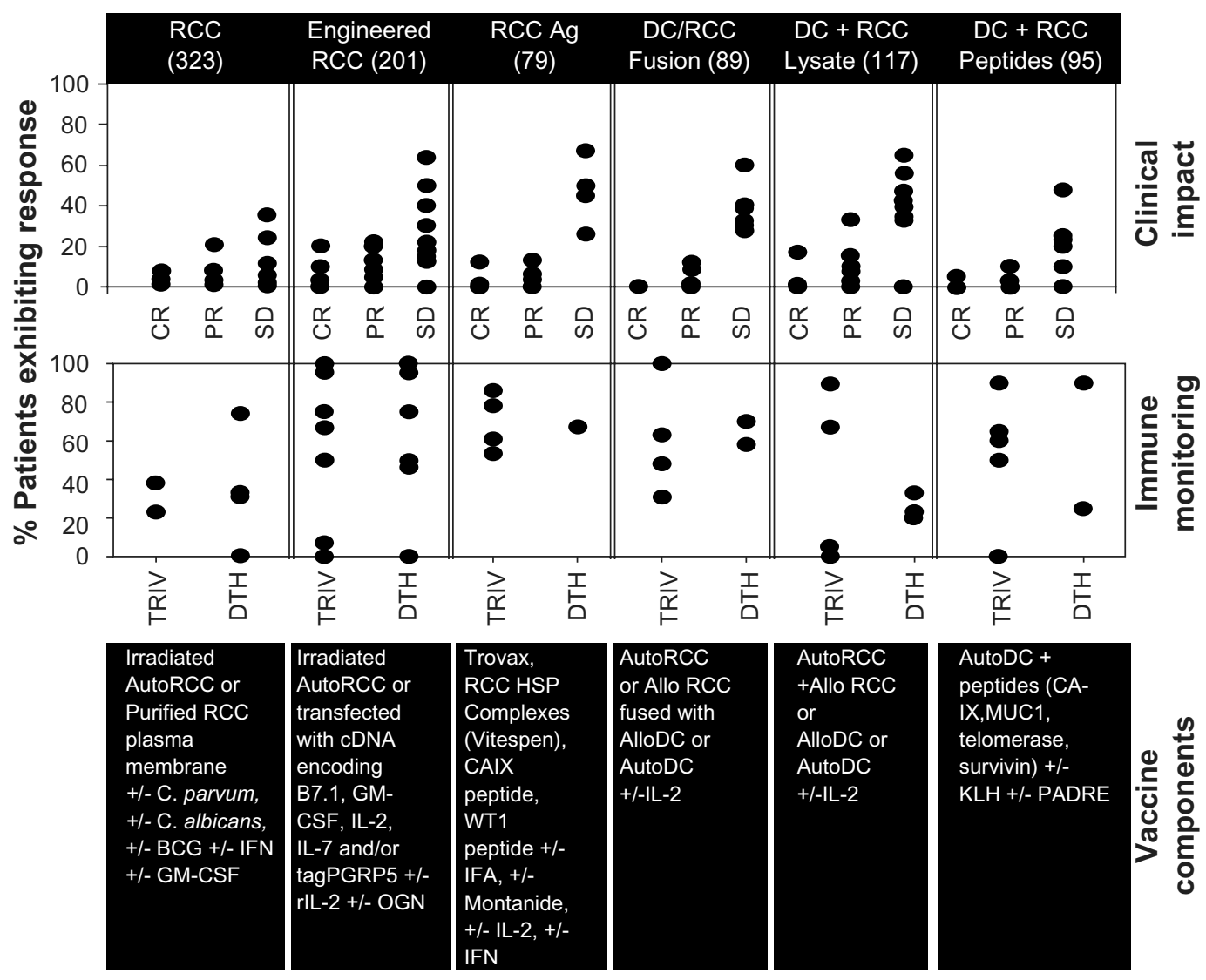

Figure 2 Renal cell carcinoma (RCC) vaccine trials: summary of clinical and immunologic monitoring results. Phase l/II clinical trials were performed in patients with RCC using one of the six indicated types of RCC-associated antigens (RCCAAs), with the cumulative number of patients treated with a given modality indicated in parentheses. RECIST criteria were applied to define patient response to therapy: CR, complete response; PR, partial response; SD, stable disease. The bottom panels show the components used in individual clinical trials. Data are only summarized from published trials in which coordinate immune monitoring for specific T-cell reactivity post- vs prevaccination was performed. Immune monitoring was performed by assessing T-cell responses in vitro (TRIV) using proliferation or cytotoxicity assays, or via the analysis of IFN- $\gamma$ production by T cells using intracellular staining (in concert with flow cytometry), ELISA or ELISPOT assays. Alternatively, type-I T-cell responses were deduced based on cutaneous delayed type hypersensitivity (DTH) responses to vaccines in vivo. We report the percentage of treated patients exhibiting specific clinical impact outcomes and increases in specific T-cell responses based on the immune monitoring criteria established for a given protocol. Each filled circle represents the data reported for an individual clinical trial.

clonal T-cell responses (ie, cytokine [IFN- $\gamma]$ enzyme-linked immunosorbent spot [ELISPOT] assays, intracellular staining of T cells for cytokine [predominantly IFN- $\gamma$ ] production and reactivity of $\mathrm{T}$ cells with fluorescently-labeled, recombinant MHC-tumor peptide multimers). The merits and perceived weaknesses of these various methods have been well discussed in the past. ${ }^{73-75}$

Here, we provide a sample of the reported clinical trial data, which strongly support the capacity of RCC vaccines (implementing each of the 6 major formulations shown in Figure 2) to promote an increase in RCC-specific T-cell responsiveness. Although the frequency of immunologically responsive patients was highly variable within a given treatment type, the majority of treated patients in many cases exhibited detectable increases in TRIV at some point after vaccination. Similarly, DTH analyses suggest that RCC vaccines have been generally competent to promote tissue inflammation at sites of vaccination (mediated by type-1 T cells, as shown in Figure 2). However, detectable TRIV and DTH as determined by current methods, even at high percentages, do not seem to directly correlate with the clinical outcome.

The general consensus regarding the immunologic monitoring of cancer patients receiving immunotherapy is that more than one assay system should be applied to monitor the changes in a patient's T-cell immune response to specific antigens. However, there are currently no acknowledged immunologic surrogate markers associated with OCR in treated cancer patients. Nevertheless, a number of vaccine trials have reported that 1) patients exhibiting OCR do typically fall within the cohort of patients exhibiting increased specific T-cell responses after vaccination; ${ }^{41,76}$ 2) clinical benefit may be associated with an increased ratio of $\mathrm{CD}^{+}$ T effector cells vs Treg cells; ${ }^{56,57} 3$ ) patients exhibiting OCR may have an expansion in their functional - cell repertoire against RCCAA specificities that were not included in the 
vaccine formulation (ie, "epitope spreading"); and (4) patient pretreatment levels of type-1 chemokines, such as IP-10, in serum may portend to better clinical outcome. ${ }^{72}$ Data collected from animal tumor models have shown that the effectiveness of a given vaccine or immunotherapy was linked to the recruitment of RCCAA-specific T effector cells into the TME via CXCR3 ligands, such as IP-10/CXCL10. Interestingly, in vitro studies have shown that IP-10 may promote apoptosis of $\mathrm{CXCR} 3 \mathrm{~B}^{+}$vascular endothelial cells (VECs) in the TME, implicating the role of at least this particular type-1 chemokine in regulating angiogenesis. ${ }^{77}$

\section{Combinational RCC vaccines: rationale and past efforts}

Thus, existing RCC vaccine platforms increase the frequency of circulating anti-RCC T cells (and antibodies) based on immunological readouts established as secondary end points in clinical trials performed to date. However, few things remain completely unclear: (1) what threshold of such antitumor $T$ cells must be reached to be biologically active against tumor? (2) what (poly)functionality and operational avidity should these $\mathrm{T}$ effectors exhibit in the TME (or elsewhere) to promote optimal antitumor impact? (3) do optimized vaccines include a risk of autoimmune pathology by inducing high-avidity $\mathrm{T}$ effector cells capable of recognizing normal tissues expressing low levels of "self" RCCAA? or (4) would even the most immunostimulatory approaches be dampened via normal compensatory mechanisms as bursts in Treg numbers have been reported in certain RCC vaccine trials? ${ }^{72,78}$ If "epitope spreading" in the T-cell repertoire is indeed a requisite to achieve and maintain objective clinical benefits, it will also be critical to normalize DC function within the TME. Specifically, it will be important to foster the ability of these APCs to effectively and reiteratively cross-prime antitumor $\mathrm{T}$ cells, some of which have to be retained for extended periods as memory cells.

Table 2 provides a partial list of additional immunomodulatory agents that could reinforce existing RCC vaccines by impacting the adaptive response at various levels suggested in Figure 1, namely, by (1) facilitating the process of cross-priming by normalizing APC function in the TME; (2) expanding the pool of treatment-induced antitumor T cells and improving their survival; (3) enhancing the function of these cells, including conversion into memory cells; (4) enhancing the recruitment of such T cells into the TME; and (5) reducing the suppression of T effector cells mediated by myeloid-derived suppressor cells (MDSCs) and Treg cells. Although we have indicated in a qualitative manner whether a given agent is likely to benefit or detract from a given biological parameter based on findings in the literature, it is important to acknowledge that no agent is perfectly suited to address all aspects in optimizing the therapeutic paradigm. Combinations of multiple agents may be necessary to yield complementary benefits. Realistically, such multicomponent vaccines may also have significant off-target toxicities, including the aforementioned autoimmune sequela that will require careful clinical monitoring. For instance, two of three RCC patients treated with autologous $\mathrm{T}$ cells engineered to express a high-avidity $\mathrm{T}$ cell receptor (TCR) reactive against the CA-IX (G250) RCCAA developed severe liver toxicity due to T-cell targeting of CA-IX expressed by bile duct epithelial cells. ${ }^{79}$

To a certain degree, the process of developing combinational RCC vaccines has been initiated in phase I/II trials, based on the use of long-standing cytokines, such as IL-2, IFN- $\alpha$, IFN- $\gamma$, and GM-CSF, as "adjuvants" to support the function of $\mathrm{T}$ cells and DCs. Other cotherapeutics such as ONTAK $^{\circledR}$ (Ligand Pharmaceuticals, LaJolla, CA, USA) (anti-CD25), CTLA-4Ig, or all-trans retinoic acid (ATRA) have been used to alleviate the inhibitory action of Treg cells and/or MDSCs. However, only a limited number of prospective randomized trials have been conducted till date.

Fenton et $\mathrm{l}^{80}$ reported minimal impact of treating RCC patients with an irradiated, autologous tumor cell vaccine in concert with low- or high-dose of recombinant human interleukin (rhIL-2) vs the tumor vaccine alone in a phase I trial. This lack of benefit may relate, at least in part, to the well-known ability of rhIL-2 to support Treg expansion in treated patients. ${ }^{78,81}$ In a phase II study evaluating the efficacy of a MVA vaccine encoding the RCCAA 5T4 (TroVax) plus recombinant interferon $\alpha$ (rIFN- $\alpha$ ), no benefit was observed in the cohort of patients receiving IFN- $\alpha$ cotherapy. ${ }^{59}$ Indeed, patients treated with vaccine + IFN- $\alpha$ tended to be less likely to exhibit antigen-specific TRIV and displayed shorter median progression-free survival and median overall survival when compared with patients treated with the vaccine alone. No rationale for this regulatory effect was suggested, but it is conceivable that the potent antiviral activity of IFN- $\alpha$ promotes more rapid viral clearance by activating neutralizing antibodies or antiviral $\mathrm{T}$ cells and actually limits the efficacy of booster vaccinations in patients receiving the TroVax vaccine.

In contrast to the aforementioned studies, patients with RCC receiving vaccines containing Newcastle virus-infected, irradiated, autologous RCC cells in combination with low dose of rhIL-2 and recombinant human interferon $\alpha 2 \mathrm{a}$ 
Table 2 Potential vaccine coimmunotherapeutics.

\begin{tabular}{|c|c|c|c|c|c|c|}
\hline \multirow[t]{2}{*}{ Cotherapeutic agent } & \multicolumn{6}{|c|}{ Expected impact on Teff vs suppressor cells } \\
\hline & Teff priming & Teff function & Teff survival & Teff (TME) & Treg/MDSC & References \\
\hline \multicolumn{7}{|l|}{ Cytokines } \\
\hline IL-2 & $\uparrow$ & $\uparrow$ & $+1-$ & $\uparrow$ & $\uparrow($ Treg $)$ & $173-175$ \\
\hline IL-7 & $\uparrow$ & $\uparrow$ & $\uparrow$ & $\uparrow$ & $\uparrow($ Treg) & $176-178$ \\
\hline IL-I2 & $\uparrow$ & $\uparrow$ & $\uparrow$ & $\uparrow$ & $-($ Treg), $\downarrow$ (MDSC) & $|79-18|$ \\
\hline IL-15 & $\uparrow$ & $\uparrow$ & $\uparrow$ & $\uparrow$ & $\uparrow(\text { Treg) })^{*}$ & 182,183 \\
\hline IL-18 & $\uparrow$ & $\uparrow$ & $\uparrow$ & $?$ & $\downarrow$ (Treg) & $184-186$ \\
\hline IL-2I & $\uparrow$ & $\uparrow$ & $\uparrow$ & $\uparrow$ & +l- (Treg) & $187-190$ \\
\hline IFN- $\alpha$ & $\uparrow$ & $\uparrow$ & $\uparrow$ & $\uparrow$ & +l- (Treg) & $175,191-194$ \\
\hline IFN- $\gamma$ & $\uparrow$ & $\uparrow$ & $-?$ & $\uparrow$ & $\downarrow$ (Treg) & $195-197$ \\
\hline GM-CSF & $\uparrow$ & $\uparrow$ & $\uparrow$ & $\uparrow$ & $\downarrow$ (Treg) & $198-202$ \\
\hline \multicolumn{7}{|l|}{ Coinhibitory antagonist } \\
\hline CTLA-4 & $\uparrow$ & $\uparrow$ & $?$ & $\uparrow$ & $\downarrow$ (Treg) & 203,204 \\
\hline PDI/PDIL & $\uparrow$ & $\uparrow$ & $\uparrow$ & $\uparrow$ & $\downarrow$ (Treg) & $205-207$ \\
\hline \multicolumn{7}{|l|}{ Costimulatory agonist } \\
\hline CD40/CD40L & $\uparrow$ & $\uparrow$ & $\uparrow$ & $\uparrow$ & $\uparrow($ Treg); $\uparrow(M D S C)$ & $208-211$ \\
\hline GITR/GITRL & $\uparrow$ & $\uparrow$ & $\uparrow$ & $\uparrow$ & $\downarrow$ (Treg); $\downarrow$ (MDSC) & 212,213 \\
\hline OX40/OX86 & $\uparrow$ & $\uparrow$ & $\uparrow$ & $\uparrow$ & $\downarrow$ (Treg); $\downarrow$ (MDSC) & $214-219$ \\
\hline 4-IBB/4-IBBL & $\uparrow$ & $\uparrow$ & $\uparrow$ & $\uparrow$ & 个 (Treg) & $220-224$ \\
\hline \multicolumn{7}{|l|}{ TLR agonists } \\
\hline Imiquimod (TLR7) & $\uparrow$ & $\uparrow$ & $\uparrow$ & $\uparrow$ & $?$ & $225-227$ \\
\hline Resiquimod (TLR8) & $\uparrow$ & $\uparrow$ & $\uparrow$ & $?$ & $?$ & 228,229 \\
\hline$C_{p} G$ (TLR9) & $\uparrow$ & $\uparrow$ & $\uparrow$ & $\uparrow$ & $\downarrow$ (Treg) & $230-232$ \\
\hline \multicolumn{7}{|l|}{ Antiangiogenic } \\
\hline VEGF-trap & - & - & $?$ & $?$ & - & 233 \\
\hline Sunitinib & $\uparrow$ & $\uparrow$ & $?$ & $\uparrow$ & $\downarrow($ Treg/MDSC) & $98,100,234$ \\
\hline Sorafenib & $\downarrow$ & $\downarrow$ & $\downarrow$ & $?$ & $\downarrow$ (MDSC) & 235 \\
\hline Bevacizumab & $\uparrow$ & $\uparrow$ & $?$ & $?$ & $\downarrow$ (MDSC) & 236,237 \\
\hline Gefitinib (IRESSA) & $?$ & $?$ & $?$ & $?$ & $?$ & 238,239 \\
\hline Cetuximab & $?$ & $\uparrow$ & $?$ & $?$ & $?$ & 240 \\
\hline \multicolumn{7}{|l|}{ mTOR inhibitors } \\
\hline Temsirolimus/everolimus & $\downarrow$ & $\downarrow$ & $\downarrow$ & $?$ & $\downarrow$ (Treg) & 241 \\
\hline \multicolumn{7}{|l|}{ Treg/MDSC inhibitors } \\
\hline Iplimumab (CTLA-4) & $\uparrow$ & $\uparrow$ & $?$ & $\uparrow$ & $\downarrow$ (Treg) & 242,243 \\
\hline ONTAK (CD25) & $+l-$ & $+1-$ & $?$ & $?$ & $\downarrow$ (Treg) & 244 \\
\hline Anti-TGF $\beta / T G F \beta R$ & $\uparrow$ & $\uparrow$ & $\uparrow$ & $\uparrow$ & $\downarrow$ (Treg) & $245-247$ \\
\hline Anti-ILIO/ILIOR & $\uparrow$ & $\uparrow$ & $\uparrow$ & $+1-$ & $\downarrow$ (Treg) & 248,249 \\
\hline Anti-IL35/IL35R & $\uparrow ?$ & $\uparrow ?$ & $\uparrow ?$ & $\uparrow ?$ & $\downarrow$ (Treg) & 250 \\
\hline I-Methyl trytophan & $\uparrow$ & $\uparrow$ & $?$ & $?$ & $\downarrow$ (MDSC) & 251 \\
\hline ATRA & $\uparrow$ & $\uparrow$ & $?$ & $?$ & $\uparrow($ Treg), $\downarrow$ (MDSC) & $90-93$ \\
\hline
\end{tabular}

Note: Agents that are currently or soon-to-be used in clinical trials are summarized with regard to their anticipated impact(s) on type-I antitumor $\mathrm{T}_{\text {cell }}\left(\mathrm{T}_{\mathrm{e}}\right)$ activation, function, survival, and recruitment into the TME. Additional anticipated effects of drugs on suppressor cells (Treg and MDSCs) are also summarized.

Key: $\uparrow$, agent is expected to increase parameter; $\downarrow$, agent is expected to inhibit parameter; $+/-$, minimal increase or decrease is expected in parameter as a consequence of treatment with agent; ?, unknown effect of agent on parameter.

Abbreviations: ATRA, all-trans retinoic acid; CTLA-4, cytotoxic T lymphocyte antigen 4; GITR(L), glucocorticoid-induced TNF receptor (ligand); GM-CSF, granulocyte macrophage-colony-stimulating factor; IFN, interferon; IL, interleukin; MDSC, myeloid-derived suppressor cell; PDI/PDIL, programmed cell death I (ligand); TGF- $\beta$ (R), tumor necrosis factor- $\beta$ (receptor); TLR, Toll-like receptor; TME, tumor microenvironment; Treg, regulatory T cell; VEGF, vascular endothelial growth factor.

(rhIFN- $\alpha 2 \mathrm{a}$ ) appeared to display improved relapse-free and overall survival when compared with the cohort of patients receiving only the vaccine. ${ }^{82}$ Furthermore, combinational therapy benefit was also suggested in a study by Simons et $\mathrm{al}^{83}$ who performed a randomized, double-blinded phase II study comparing the efficacy of vaccines composed of control or GM-CSF cDNA-engineered autologous, irradiated RCC cells. In this trial, the GM-CSF-engineered vaccine was well tolerated with no dose-limiting toxicities or autoimmunity reported. It appeared to be capable of promoting superior 
type-1 T-cell response to RCCAA (based on patient DTH readouts) when compared with vaccines composed of control tumor cells alone. Dannull et al have shown that partial depletion of Treg cells using ONTAK, an anti-CD25 antibody coupled to diphtheria toxin, conditions the patients with RCC for improved type-1 T-cell responses against autologous DCs transfected with mRNA isolated from autologous tumor cells. ${ }^{84}$ However, its impact on the clinical course was not reported. A recent phase I/II study by Holtl et al used allogenic DCs pulsed with autologous tumor lysates in conjunction with cyclophosphamide (CY) pretreatment to deplete Treg cells and provide "space" for homeostatic T-cell expansion. Results showed only a slight improvement in patients treated with $\mathrm{CY}$, with a median overall survival of 23.2 months vs 20.3 months without $\mathrm{CY} .^{85}$

\section{Combinational RCC vaccines: moving forward}

A plethora of agents exist for consideration in the design of combinational vaccines (Table 2). Going forward, it will be crucial that all vaccine trials develop as randomized, prospective protocols that integrate secondary immunologic end points. These immunological end points must determine the actual impact of the vaccine on RCC-specific T-cell responses over the duration of the study. This will be important not only to validate whether the perceived immunologic benefits of the combined approach are indeed met, but also to see how well they are met, so that future trials may be designed using agents that further augment or complement mechanisms currently believed to underlie optimal immunotherapeutic benefit.

In 2007, the NCI Immunotherapy Agent Workshop established a list of the top 20 (from among 124) agents that were considered by participants to have a high likelihood for efficacy in cancer therapy. ${ }^{86}$ Thirteen of these top 20 are cited in Table 2, including IL-15; anti-PD-1 (or anti-B7-H1); IL-12; anti-CD40 and/or anti-CD40L; IL-7, CpG, 1-MT, anti-4-1BB; anti-TGF- $\beta$; anti-IL10 or anti-IL10R; anti-GITR; anti-OX40; and resiquimod. As the merits of these agents are well delineated with regard to shaping, sustaining, and directing antitumor T-cell responses in the NCI Workshop report, we will focus our attention on a small cohort of these agents in the following paragraphs.

A major barrier to effective vaccine therapy in RCC is the immune regulatory component in cancer patients. As such, eradication or inhibition of Treg cells and MDSCs would promote vaccine efficacy. One mechanism that some groups have been targeting is CTLA-4 signaling of Treg cells. ${ }^{84}$ CTLA-4 blockade has been applied as a monotherapy for RCC, where it has been reported to yield partial clinical responses (PRs) in approximately $25 \%$ of treated patients with RCC for up to 18 months. ${ }^{87}$ However, autoimmune hypophysitis and colitis have been reported in patients with RCC receiving CTLA-4-blocking agents. ${ }^{88,89}$ Such toxicities might be exacerbated by vaccine combinations and will require careful monitoring in prospective clinical trials.

It has recently been reported by multiple groups that ATRA can ablate the number and/or suppressive function of MDSCs, while augmenting the function of DCs isolated from patients with RCC resulting in improved type-1 TRIV. ${ }^{90,91}$ Furugaki et $\mathrm{al}^{92}$ have also shown that ATRA serves as an effective adjuvant when combined with genetic immunization, promoting long-term survival in a murine promyelocytic leukemia model. However, ATRA has also been reported to regulate the balance between developing Treg vs Th17 cell responses in the $\mathrm{CD}^{+}{ }^{+} \mathrm{T}$-cell compartment, favoring the Treg outcome. ${ }^{93}$ This seems to be based on signals mediated via nuclear retinoic acid receptor- $\alpha$ (RAR $\alpha$ ), making ATRA (or other RAR $\alpha$ antagonists) a potential double-edged sword when considering the design of combinational RCC vaccines.

Intriguing candidates for integration into combination RCC vaccine design include small molecules, such as tyrosine kinase inhibitors (TKIs). Several clinical trials have utilized TKIs to inhibit various RTKs, such as vascular endothelial growth factor receptor (VEGFR), as an antiangiogenic agent to treat RCC. One such TKI is sunitinib, which has exhibited pronounced (albeit transient) efficacy in phase I/II clinical trials as a first-line treatment for patients with RCC. ${ }^{94-96}$ Even though this drug was initially developed as an antiangiogenic agent, a series of very recent reports suggest that patients treated with sunitinib exhibit reductions in peripheral blood levels of MDSCs and Treg cell populations and normalized type-1 TRIV after mitogenic stimulation. ${ }^{97-100}$ Murine tumor modeling suggests that sunitinib suppresses STAT3 activation ${ }^{101}$ and bolsters the efficacy of immunogenetherapy by promoting RCCAA-specific $\mathrm{T}$ effector cells and concomitantly suppressing MDSCs and Treg cells in vivo. ${ }^{98,99,102}$ Alternative TKIs, such as sorafenib (which currently serves as a second-line therapy for RCC), may not be as preferred as a vaccine or cotherapeutic agent, given its reported inhibitory effects on DCs and T cells. ${ }^{103}$ An additional immunotherapeutic benefit of sunitinib and other antiangiogenic drugs, is predicated on their ability to "normalize" the tumor vasculature, leading to a decrease in interstitial fluid pressure and improved delivery of 
chemotherapeutic drugs and effector T cells into the TME. ${ }^{104}$ However, enhanced T-cell infiltration into the TME is not a passive event. Our group has recently shown that sunitinib activates tumor VEC expression of VCAM-1 and Mig (CXCL9), which serve to recruit $\left(\mathrm{CXCR}^{+}\right)$type-1 tumor infiltrating lymphocyte (TIL) (unpublished data). In theory, sunitinib cotherapy may condition the TME for improved recruitment and sustained function of RCC vaccine-induced T effector cells, ${ }^{105}$ thereby prolonging the dramatic early OCR characteristic of sunitinib.

\section{Summary and additional considerations}

Early clinical results published over a decade ago showed that IFN- $\alpha_{2 \mathrm{a}}$ - and IL-2-based immunotherapy provided survival advantage to patients compared with control groups. ${ }^{106,107}$ However, a recent study has called these earlier findings into question by demonstrating that there may be little survival benefit from either of these cytokines when applied alone or in combination, and that they may induce a significant risk of toxicity. ${ }^{108}$ IL-2 is known to promote Treg cell responses in vitro and in vivo. ${ }^{109}$ As such, its less-than-ideal activity might have been predicted, given its ability to potentiate aspects of the dysfunctional or inappropriate polarization by the adaptive immune system in the majority of patients with tumors. ${ }^{78,110}$ Given the information, we have collated and proposed that a successful combinational therapeutic platform must include the integration of appropriate immunogeneic tumor antigens in order to focus immunity toward carcinoma cells with adjuvants that activate and "license" APCs to preferentially prime or activate type-1 antitumor $\mathrm{T}$ cells plus additional stimuli that may 1) support vaccine-activated T-cell survival, resistance to tumor-induced immune deviation and conversion to memory status; 2) prevent or remove the opposing influence of existing immune suppression (tumor, MDSC, Treg); 3) normalize the TME, thereby allowing for improved delivery of vaccine-induced $\mathrm{T}$ effector cells (and type-1 APCs) into the TME; and 4) promote reiterative rounds of T-cell cross-priming in the tumor draining lymph nodes leading to an expansion in the functional antitumor T-cell repertoire via a process akin to "epitope spreading" (a classical autoimmune paradigm). In such optimized protocols, one would expect a minor cohort of patients to exhibit a complete response (based on RECIST criteria), but perhaps of equal importance, a sizeable cohort of patients develop stabilization of their disease or tumor dormancy. If vaccines are successful in attaining even a transient state of dominance for type-1 antitumor immunity, one would predict the consequential development of compensatory regulatory immunity to limit this "autoimmunity", allowing for the resumed growth of micro- or macroscopic metastases. Given such concerns, and despite their potential to unveil untoward autoimmune pathology, maintenance booster vaccines will likely be mandated to significantly prolong median time to progression and overall survival.

Notably, it has recently also become possible to consider the immune targeting of the tumor vasculature based on vaccines formulated using antigens that are differentially expressed by either VECs (ie, EphA2) ${ }^{111}$ or pericytes (ie, PDGFR $\beta^{112}$ or $N G 2^{113}$ ). In such cases, specific T cells may destroy or dysregulate tumor angiogenesis in a prolonged fashion (based on T-cell memory) and in a manner that is independent of other therapeutics, such as TKIs, which may put selective pressure on tumor cells. Furthermore, focusing type-1 T-cell responses on tumor-associated vascular cells may foster corollary recruitment (based on CXCR3 ligand chemokine production and endothelial cell expression of VCAM-1) of type- $1 \mathrm{~T}$ cells that have been cross-primed against additional RCCAAs.

We have come far in the past decade in developing a better understanding of how the immune system recognizes RCC and how the optimal function of protective anti-RCC T-cell-mediated immunity may be altered in chronic disease states. Only now, we are becoming skilled at applying agents in the appropriate combinations, quantities, and schedules to allow for the normalization and maintenance of protective immunity. By adopting a stepwise progression through randomized prospective trials integrating sensitive and appropriate immunomonitoring methodologies, we will soon develop a consensus regarding optimal (combinational) vaccine-based immunotherapy approaches for the treatment of RCC. Upon consideration of the frustration in treating metastatic RCC and the distress of such patients, combinational protocols that integrate anti-RCCAA vaccines and angiogenic inhibitors promoting tumor apoptosis should be prioritized in the immediate future, as such strategies may greatly improve the outcome of patients with advancedstage disease.

\section{Acknowledgments}

This work was supported by the National Institutes of Health (NIH) grants R01 CA114071 and P01 CA109688 (to WJS).

\section{Disclosure}

The authors report no conflicts of interest in this work. 


\section{References}

1. Rohrmann K, Staehler M, Haseke N, Bachmann A, Stief CG, Siebels M. Immunotherapy in metastatic renal cell carcinoma. World J Urol. 2005; 23(3):196-201.

2. Finke JH, Tubbs R, Connelly B, Pontes E, Montie J. Tumor-infiltrating lymphocytes in patients with renal-cell carcinoma. Ann N Y Acad Sci. 1988;532:387-394.

3. Finke JH, Rayman P, Edinger M, et al. Characterization of a human renal cell carcinoma specific cytotoxic CD8+ T cell line. J Immunother. 1992;11(1):1-11.

4. Muul LM, Spiess PJ, Director EP, Rosenberg SA. Identification of specific cytolytic immune responses against autologous tumor in humans bearing malignant melanoma. J Immunol. 1987;138(3):989-995.

5. Schendel DJ, Gansbacher B, Oberneder R, et al. Tumor-specific lysis of human renal cell carcinomas by tumor-infiltrating lymphocytes. I. HLA-A2-restricted recognition of autologous and allogeneic tumor lines. J Immunol. 1993;151(8):4209-4220.

6. Ritchie AW, deKernion JB. The natural history and clinical features of renal carcinoma. Semin Nephrol. 1987;7(2):131-139.

7. Lokich J. Spontaneous regression of metastatic renal cancer. Case report and literature review. Am J Clin Oncol. 1997;20(4):416-418.

8. Penn I. Primary kidney tumors before and after renal transplantation. Transplantation. 1995;59(4):480-485.

9. Kolbeck PC, Kaveggia FF, Johansson SL, Grune MT, Taylor RJ. The relationships among tumor-infiltrating lymphocytes, histopathologic findings, and long-term clinical follow-up in renal cell carcinoma. Mod Pathol. 1992;5(4):420-425.

10. Hernberg M. Lymphocyte subsets as prognostic markers for cancer patients receiving immunomodulative therapy. Med Oncol. 1999;16(3):145-153.

11. Nakano O, Sato M, Naito Y, et al. Proliferative activity of intratumoral CD8(+) T-lymphocytes as a prognostic factor in human renal cell carcinoma: clinicopathologic demonstration of antitumor immunity. Cancer Res. 2001;61(13):5132-5136.

12. Kondo T, Nakazawa H, Ito F, et al. Favorable prognosis of renal cell carcinoma with increased expression of chemokines associated with a Th1-type immune response. Cancer Sci. 2006;97(8):780-786.

13. Troy AJ, Summers KL, Davidson PJ, Atkinson CH, Hart DN. Minimal recruitment and activation of dendritic cells within renal cell carcinoma. Clin Cancer Res. 1998;4(3):585-593.

14. Uzzo RG, Rayman P, Kolenko V, et al. Mechanisms of apoptosis in $\mathrm{T}$ cells from patients with renal cell carcinoma. Clin Cancer Res. 1999;5(5):1219-1229.

15. Kiertscher SM, Luo J, Dubinett SM, Roth MD. Tumors promote altered maturation and early apoptosis of monocyte-derived dendritic cells. J Immunol. 2000;164(3):1269-1276.

16. Rayman P, Wesa AK, Richmond AL, et al. Effect of renal cell carcinomas on the development of type 1 T-cell responses. Clin Cancer Res. 2004;10(18 Pt 2):6360S-6366S.

17. Tatsumi T, Herrem CJ, Olson WC, et al. Disease stage variation in $\mathrm{CD}^{+}$and $\mathrm{CD} 8+\mathrm{T}$-cell reactivity to the receptor tyrosine kinase EphA2 in patients with renal cell carcinoma. Cancer Res. 2003;63(15):4481-4489.

18. Tatsumi T, Kierstead LS, Ranieri E, et al. Disease-associated bias in T helper type 1 (Th1)/Th2 CD4+ T cell responses against MAGE-6 in HLA-DRB1*0401+ patients with renal cell carcinoma or melanoma. J Exp Med. 2002;196(5):619-628.

19. Onishi T, Ohishi Y, Imagawa K, Ohmoto Y, Murata K. An assessment of the immunological environment based on intratumoral cytokine production in renal cell carcinoma. BJU Int. 1999;83(4):488-492.

20. Griffiths RW, Elkord E, Gilham DE, et al. Frequency of regulatory T cells in renal cell carcinoma patients and investigation of correlation with survival. Cancer Immunol Immunother. 2007;56(11): 1743-1753.

21. Saff RR, Spanjaard ES, Hohlbaum AM, Marshak-Rothstein A. Activation-induced cell death limits effector function of CD4 tumorspecific T cells. J Immunol. 2004;172(11):6598-6606.
22. Lu B, Finn OJ. T-cell death and cancer immune tolerance. Cell Death Differ. 2008;15(1):70-79.

23. Giermasz AS, Urban JA, Nakamura Y, et al. Type-1 polarized dendritic cells primed for high IL-12 production show enhanced activity as cancer vaccines. Cancer Immunol Immunother. 2009;58(8):1329-1336.

24. Kapsenberg ML. Dendritic-cell control of pathogen-driven T-cell polarization. Nat Rev Immunol. 2003;3(12):984-993.

25. Melief CJ. Cancer immunotherapy by dendritic cells. Immunity. 2008; 29(3):372-383.

26. Radhakrishnan S, Wiehagen KR, Pulko V, et al. Induction of a Th1 response from Th2-polarized T cells by activated dendritic cells: dependence on TCR: peptide-MHC interaction, ICAM-1, IL-12, and IFN- $\gamma^{1}$. J Immunol. 2007;178(6):3583-3592.

27. Krawczyk CM, Shen H, Pearce EJ. Functional plasticity in memory T helper cell responses. J Immunol. 2007;178(7):4080-4088.

28. Arroyo JC, Gabilondo F, Llorente L, Meraz-Rios MA, SanchezTorres C. Immune response induced in vitro by CD16- and CD16+ monocyte-derived dendritic cells in patients with metastatic renal cell carcinoma treated with dendritic cell vaccines. J Clin Immunol. 2004; 24(1):86-96.

29. Wesa A, Kalinski P, Kirkwood JM, Tatsumi T, Storkus WJ. Polarized type-1 dendritic cells (DC1) producing high levels of IL-12 family members rescue patient TH1-type antimelanoma CD4+ T cell responses in vitro. J Immunother. 2007;30(1):75-82.

30. Lipscomb MW, Chen L, Taylor JL, et al. Ectopic T-bet expression licenses dendritic cells for IL-12-independent priming of type $1 \mathrm{~T}$ cells in vitro. J Immunol. 2009;183(11):7250-7258.

31. Uemura H, Fujimoto K, Tanaka M, et al. A phase I trial of vaccination of CA9-derived peptides for HLA-A24+ patients with cytokine-refractory metastatic renal cell carcinoma. Clin Cancer Res. 2006;12(6):1768-1775.

32. Iiyama T, Udaka K, Takeda S, et al. WT1 (Wilms' tumor 1) peptide immunotherapy for renal cell carcinoma. Microbiol Immunol. 2007;51(5):519-530.

33. Rahma OE, Ashtar E, Ibrahim R, et al. A pilot clinical trial testing mutant von Hippel-Lindau peptide as a novel immune therapy in metastatic renal cell carcinoma. J Transl Med. 8:8.

34. Miller GA, Pontes JE, Huben RP, Goldrosen MH. Humoral immune response of patients receiving specific active immunotherapy for renal cell carcinoma. Cancer Res. 1985;45(9):4478-4482.

35. Tani K, Nakazaki Y, Hase H, et al. Progress reports on immune gene therapy for stage IV renal cell cancer using lethally irradiated granulocyte-macrophage colony-stimulating factor-transduced autologous renal cancer cells. Cancer Chemother Pharmacol. 2000;46 Suppl:S73-S76.

36. Maini A, Nishisaka N, Kinoshita Y, Jones RF, Wang CY, Haas GP. Combination of radiation and vaccination with autologous tumor cells expressing IL-2, IFN-gamma and GM-CSF for treatment of murine renal carcinoma. In vivo. 2003;17(2):119-123.

37. Avigan DE, Vasir B, George DJ, et al. Phase I/II study of vaccination with electrofused allogeneic dendritic cells/autologous tumor-derived cells in patients with stage IV renal cell carcinoma. J Immunother. 2007;30(7):749-761.

38. Heiser A, Maurice MA, Yancey DR, Coleman DM, Dahm P, Vieweg J. Human dendritic cells transfected with renal tumor RNA stimulate polyclonal T-cell responses against antigens expressed by primary and metastatic tumors. Cancer Res. 2001;61(8):3388-3393.

39. Geiger C, Regn S, Weinzierl A, Noessner E, Schendel DJ. A generic RNA-pulsed dendritic cell vaccine strategy for renal cell carcinoma. J Transl Med. 2005;3:29.

40. Su Z, Dannull J, Heiser A, et al. Immunological and clinical responses in metastatic renal cancer patients vaccinated with tumor RNA-transfected dendritic cells. Cancer Res. 2003;63(9):2127-2133.

41. Wierecky J, Muller MR, Wirths S, et al. Immunologic and clinical responses after vaccinations with peptide-pulsed dendritic cells in metastatic renal cancer patients. Cancer Res. 2006;66(11): 5910-5918.

42. BleumerI,Tiemessen DM, Oosterwijk-WakkaJC, etal.Preliminary analysis of patients with progressive renal cell carcinoma vaccinated with CA9peptide-pulsed mature dendritic cells. JImmunother. 2007;30(1):116-122. 
43. Zamparese R, Pannone G, Santoro A, et al. Survivin expression in renal cell carcinoma. Cancer Invest. 2008;26(9):929-935.

44. Alves PM, Faure O, Graff-Dubois S, et al. EphA2 as target of anticancer immunotherapy: identification of HLA-A*0201-restricted epitopes. Cancer Res. 2003;63(23):8476-8480.

45. Scardino A, Alves P, Gross DA, et al. Identification of HER-2/neu immunogenic epitopes presented by renal cell carcinoma and other human epithelial tumors. Eur J Immunol. 2001;31(11):3261-3270.

46. Aubert S, Fauquette V, Hemon B, et al. MUC1, a new hypoxia inducible factor target gene, is an actor in clear renal cell carcinoma tumor progression. Cancer Res. 2009;69(14):5707-5715.

47. Vissers JL, De Vries IJ, Schreurs MW, et al. The renal cell carcinoma-associated antigen G250 encodes a human leukocyte antigen (HLA)-A2.1-restricted epitope recognized by cytotoxic T lymphocytes. Cancer Res. 1999;59(21):5554-5559.

48. Southall PJ, Boxer GM, Bagshawe KD, Hole N, Bromley M, Stern PL. Immunohistological distribution of 5T4 antigen in normal and malignant tissues. Br J Cancer. 1990;61(1):89-95.

49. Wykoff CC, Beasley NJ, Watson PH, et al. Hypoxia-inducible expression of tumor-associated carbonic anhydrases. Cancer Res. 2000; 60(24):7075-7083.

50. Ashida S, Nishimori I, Tanimura M, Onishi S, Shuin T. Effects of von Hippel-Lindau gene mutation and methylation status on expression of transmembrane carbonic anhydrases in renal cell carcinoma. J Cancer Res Clin Oncol. 2002;128(10):561-568.

51. Shimizu K, Uemura H, Yoshikawa M, et al. Induction of antigen specific cellular immunity by vaccination with peptides from MN/CA IX in renal cell carcinoma. Oncol Rep. 2003;10(5):1307-1311.

52. Shvarts O, Janzen N, Lam JS, et al. RENCA/carbonic anhydrase-IX: a murine model of a carbonic anhydrase-IX-expressing renal cell carcinoma. Urology. 2006;68(5):1132-1138.

53. Bauer S, Oosterwijk-Wakka JC, Adrian N, et al. Targeted therapy of renal cell carcinoma: synergistic activity of cG250-TNF and IFNg. Int J Cancer. 2009;125(1):115-123.

54. Griffiths RW, Gilham DE, Dangoor A, et al. Expression of the 5T4 oncofoetal antigen in renal cell carcinoma: a potential target for T-cellbased immunotherapy. Br J Cancer. 2005;93(6):670-677.

55. Shaw DM, Connolly NB, Patel PM, et al. A phase II study of a 5T4 oncofoetal antigen tumour-targeted superantigen (ABR-214936) therapy in patients with advanced renal cell carcinoma. Br J Cancer. 2007;96(4):567-574.

56. Amato RJ, Shingler W, Naylor S, et al. Vaccination of renal cell cancer patients with modified vaccinia ankara delivering tumor antigen 5T4 (TroVax) administered with interleukin 2: a phase II trial. Clin Cancer Res. 2008;14(22):7504-7510.

57. Kaufman HL, Taback B, Sherman W, et al. Phase II trial of Modified Vaccinia Ankara (MVA) virus expressing 5T4 and high dose Interleukin-2 (IL-2) in patients with metastatic renal cell carcinoma. J Transl Med. 2009;7:2.

58. Hawkins RE, Macdermott C, Shablak A, et al. Vaccination of patients with metastatic renal cancer with modified vaccinia Ankara encoding the tumor antigen 5T4 (TroVax) given alongside interferon-alpha. J Immunother. 2009;32(4):424-429.

59. Amato RJ, Shingler W, Goonewardena M, et al. Vaccination of renal cell cancer patients with modified vaccinia Ankara delivering the tumor antigen 5T4 (TroVax) alone or administered in combination with interferon-alpha (IFN-alpha): a phase 2 trial. J Immunother. 2009;32(7):765-772.

60. Butterfield LH, Comin-Anduix B, Vujanovic L, et al. Adenovirus MART-1-engineered autologous dendritic cell vaccine for metastatic melanoma. J Immunother. 2008;31(3):294-309.

61. Carmichael MG, Benavides LC, Holmes JP, et al. Results of the first phase 1 clinical trial of the HER-2/neu peptide (GP2) vaccine in diseasefree breast cancer patients: United States Military Cancer Institute Clinical Trials Group Study I-04. Cancer. 2010;116(2):292-301.

62. Slingluff CL Jr, Petroni GR, Yamshchikov GV, et al. Immunologic and clinical outcomes of vaccination with a multiepitope melanoma peptide vaccine plus low-dose interleukin-2 administered either concurrently or on a delayed schedule. J Clin Oncol. 2004;22(22):4474-4485.
63. Suekane S, Nishitani M, Noguchi M, et al. Phase I trial of personalized peptide vaccination for cytokine-refractory metastatic renal cell carcinoma patients. Cancer Sci. 2007;98(12):1965-1968.

64. Dakappagari NK, Sundaram R, Rawale S, Liner A, Galloway DR, Kaumaya PT. Intracellular delivery of a novel multiepitope peptide vaccine by an amphipathic peptide carrier enhances cytotoxic T-cell responses in HLA-A*0201 mice. J Pept Res. 2005;65(2): 189-199.

65. Uemura H, De Velasco MA. Tumor vaccines in renal cell carcinoma. World J Urol. 2008;26(2):147-154.

66. Asemissen AM, Brossart P. Vaccination strategies in patients with renal cell carcinoma. Cancer Immunol Immunother. 2009;58(7): 1169-1174.

67. SaengerYM, Wolchok JD. The heterogeneity of the kinetics of response to ipilimumab in metastatic melanoma: patient cases. Cancer Immun. 2008;8:1.

68. Schlom J, Arlen PM, Gulley JL. Cancer vaccines: moving beyond current paradigms. Clin Cancer Res. 2007;13(13):3776-3782.

69. Zhou J, Weng D, Zhou F, et al. Patient-derived renal cell carcinoma cells fused with allogeneic dendritic cells elicit anti-tumor activity: in vitro results and clinical responses. Cancer Immunol Immunother. 2009; 58(10):1587-1597.

70. Jocham D, Richter A, Hoffmann L, et al. Adjuvant autologous renal tumour cell vaccine and risk of tumour progression in patients with renal-cell carcinoma after radical nephrectomy: phase III, randomised controlled trial. Lancet. 2004;363(9409):594-599.

71. Berntsen A, Trepiakas R, Wenandy L, et al. Therapeutic dendritic cell vaccination of patients with metastatic renal cell carcinoma: a clinical phase 1/2 trial. J Immunother. 2008;31(8):771-780.

72. Schwaab T, Schwarzer A, Wolf B, et al. Clinical and immunologic effects of intranodal autologous tumor lysate-dendritic cell vaccine with Aldesleukin (Interleukin 2) and IFN-\{alpha $\}_{2 \mathrm{a}}$ therapy in metastatic renal cell carcinoma patients. Clin Cancer Res. 2009;15(15): 4986-4992.

73. Keilholz U, Weber J, Finke JH, et al. Immunologic monitoring of cancer vaccine therapy: results of a workshop sponsored by the Society for Biological Therapy. J Immunother. 2002;25(2):97-138.

74. Lyerly HK. Quantitating cellular immune responses to cancer vaccines. Semin Oncol. 2003;30(3 Suppl 8):9-16.

75. Nagorsen D, Scheibenbogen C, Thiel E, Keilholz U. Immunological monitoring of cancer vaccine therapy. Expert Opin Biol Ther. 2004;4(10):1677-1684.

76. Antonia SJ, Seigne J, Diaz J, et al. Phase I trial of a B7-1 (CD80) gene modified autologous tumor cell vaccine in combination with systemic interleukin-2 in patients with metastatic renal cell carcinoma. J Urol. 2002;167(5):1995-2000.

77. Feldman ED, Weinreich DM, Carroll NM, et al. Interferon gammainducible protein 10 selectively inhibits proliferation and induces apoptosis in endothelial cells. Ann Surg Oncol. 2006;13(1):125-133.

78. Lemoine FM, Cherai M, Giverne C, et al. Massive expansion of regulatory T-cells following interleukin 2 treatment during a phase I-II dendritic cell-based immunotherapy of metastatic renal cancer. Int $J$ Oncol. 2009;35(3):569-581.

79. Lamers CH, Langeveld SC, Groot-van Ruijven CM, Debets R, Sleijfer S, Gratama JW. Gene-modified T cells for adoptive immunotherapy of renal cell cancer maintain transgene-specific immune functions in vivo. Cancer Immunol Immunother. 2007;56(12):1875-1883.

80. Fenton RG, Steis RG, Madara K, et al. A phase I randomized study of subcutaneous adjuvant IL-2 in combination with an autologous tumor vaccine in patients with advanced renal cell carcinoma. J Immunother Emphasis Tumor Immunol. 1996;19(5):364-374.

81. Cesana GC, DeRaffele G, Cohen S, et al. Characterization of CD4+CD25+ regulatory $\mathrm{T}$ cells in patients treated with high-dose interleukin-2 for metastatic melanoma or renal cell carcinoma. J Clin Oncol. 2006;24(7):1169-1177.

82. Anton P, Kirchner H, Jonas U, Atzpodien J. Cytokines and tumor vaccination. Cancer Biother Radiopharm. 1996;11(5):315-318. 
83. Simons JW, Jaffee EM, Weber CE, et al. Bioactivity of autologous irradiated renal cell carcinoma vaccines generated by ex vivo granulocyte-macrophage colony-stimulating factor gene transfer. Cancer Res. 1997;57(8):1537-1546.

84. Dannull J, Su Z, Rizzieri D, et al. Enhancement of vaccine-mediated antitumor immunity in cancer patients after depletion of regulatory T cells. J Clin Invest. 2005;115(12):3623-3633.

85. Holtl L, Ramoner R, Zelle-Rieser C, et al. Allogeneic dendritic cell vaccination against metastatic renal cell carcinoma with or without cyclophosphamide. Cancer Immunol Immunother. 2005;54(7): 663-670.

86. web.ncifcrf.gov/research/brb/workshops/NCI. National Institute of Health; NCI Immunotherapy Agent Workshop Proceedings; 2007. Available from: http://web.ncifcrf.gov/research/brb/workshops/ NCI.

87. Yang JC, Beck KE, Blansfield JA, et al. Tumor regression in patients with metastatic renal cancer treated with a monoclonal antibody to CTLA4 (MDX-010) [abstract]. J Clin Oncol (ASCO Annual Meetings Proceedings). 2005;23(16s, pt I of II, June 1 Suppl):2501.

88. Blansfield JA, Beck KE, Tran K, et al. Cytotoxic T-lymphocyteassociated antigen-4 blockage can induce autoimmune hypophysitis in patients with metastatic melanoma and renal cancer. $J$ Immunother. 2005;28(6):593-598.

89. Dillard T, Yedinak CG, Alumkal J, Fleseriu M. Anti-CTLA-4 antibody therapy associated autoimmune hypophysitis: serious immune related adverse events across a spectrum of cancer subtypes. Pituitary. 2010;13(1):29-38.

90. Mirza N, Fishman M, Fricke I, et al. All-trans-retinoic acid improves differentiation of myeloid cells and immune response in cancer patients. Cancer Res. 2006;66(18):9299-9307.

91. Kusmartsev S, Su Z, Heiser A, et al. Reversal of myeloid cell-mediated immunosuppression in patients with metastatic renal cell carcinoma. Clin Cancer Res. 2008;14(24):8270-8278.

92. Furugaki K, Pokorna K, Le Pogam C, et al. DNA vaccination with all-trans retinoic acid treatment induces long-term survival and elicits specific immune responses requiring CD4+ and CD8+ T-cell activation in an acute promyelocytic leukemia mouse model. Blood. 2010;115(3):653-656.

93. Schambach F, Schupp M, Lazar MA, Reiner SL. Activation of retinoic acid receptor-alpha favours regulatory $\mathrm{T}$ cell induction at the expense of IL-17-secreting T helper cell differentiation. Eur J Immunol. 2007;37(9):2396-2399.

94. Motzer RJ, Hutson TE, Tomczak P, et al. Overall survival and updated results for sunitinib compared with interferon alfa in patients with metastatic renal cell carcinoma. [abstract] J Clin Oncol. 2009;27(22):3584-3590.

95. Gore ME, Szczylik C, Porta C, et al. Safety and efficacy of sunitinib for metastatic renal-cell carcinoma: an expanded-access trial. Lancet Oncol. 2009;10(8):757-763.

96. Escudier B, Roigas J, Gillessen S, et al. Phase II study of sunitinib administered in a continuous once-daily dosing regimen in patients with cytokine-refractory metastatic renal cell carcinoma. J Clin Oncol. 2009;27(25):4068-4075.

97. van Cruijsen H, van der Veldt AA, Vroling L, et al. Sunitinib-induced myeloid lineage redistribution in renal cell cancer patients: CD1c+ dendritic cell frequency predicts progression-free survival. Clin Cancer Res. 2008;14(18):5884-5892.

98. Finke JH, Rini B, Ireland J, et al. Sunitinib reverses type-1 immune suppression and decreases T-regulatory cells in renal cell carcinoma patients. Clin Cancer Res. 2008;14(20):6674-6682.

99. Ko JS, Zea AH, Rini BI, et al. Sunitinib mediates reversal of myeloidderived suppressor cell accumulation in renal cell carcinoma patients. Clin Cancer Res. 2009;15(6):2148-2157.

100. Ozao-Choy J, Ma G, Kao J, et al. The novel role of tyrosine kinase inhibitor in the reversal of immune suppression and modulation of tumor microenvironment for immune-based cancer therapies. Cancer Res. 2009;69(6):2514-2522.
101. Xin H, Zhang C, Herrmann A, Du Y, Figlin R, Yu H. Sunitinib inhibition of Stat3 induces renal cell carcinoma tumor cell apoptosis and reduces immunosuppressive cells. Cancer Res. 2009;69(6):2506-2513.

102. Abe F, Younos I, Westphal S, et al. Therapeutic activity of sunitinib for Her2/neu induced mammary cancer in FVB mice. Int Immunopharmacol. 2010;10(1):140-145.

103. Hipp MM, Hilf N, Walter S, et al. Sorafenib, but not sunitinib, affects function of dendritic cells and induction of primary immune responses. Blood. 2008;111(12):5610-5620.

104. Zhou Q, Guo P, Gallo JM. Impact of angiogenesis inhibition by sunitinib on tumor distribution of temozolomide. Clin Cancer Res. 2008;14(5):1540-1549.

105. Biswas S, Eisen T. Immunotherapeutic strategies in kidney cancer when TKIs are not enough. Nat Rev Clin Oncol. 2009;6(8):478-487.

106. Flessner MF, Dedrick RL. Tissue-level transport mechanisms of intraperitoneally-administered monoclonal antibodies. J Control Release. 1998;53(1-3):69-75.

107. Pyrhonen S, Salminen E, Ruutu M, et al. Prospective randomized trial of interferon alfa-2a plus vinblastine versus vinblastine alone in patients with advanced renal cell cancer. $J$ Clin Oncol. 1999;17(9):2859-2867.

108. Negrier S, Perol D, Ravaud A, et al. Medroxyprogesterone, interferon alfa-2a, interleukin 2 , or combination of both cytokines in patients with metastatic renal carcinoma of intermediate prognosis: results of a randomized controlled trial. Cancer. 2007;110(11):2468-2477.

109. Zhang H, Chua KS, Guimond M, et al. Lymphopenia and interleukin-2 therapy alter homeostasis of CD4+CD25+ regulatory T cells. Nat Med. 2005;11(11):1238-1243.

110. Jensen HK, Donskov F, Nordsmark M, Marcussen N, von der Maase $\mathrm{H}$. Increased intratumoral FOXP3-positive regulatory immune cells during interleukin-2 treatment in metastatic renal cell carcinoma. Clin Cancer Res. 2009;15(3):1052-1058.

111. Ogawa K, Pasqualini R, Lindberg RA, Kain R, Freeman AL, Pasquale EB. The ephrin-A1 ligand and its receptor, EphA2, are expressed during tumor neovascularization. Oncogene. 2000;19(52):6043-6052.

112. Abramsson A, Lindblom P, Betsholtz C. Endothelial and nonendothelial sources of PDGF-B regulate pericyte recruitment and influence vascular pattern formation in tumors. $J$ Clin Invest. 2003;112(8):1142-1151

113. Ozerdem U, Monosov E, Stallcup WB. NG2 proteoglycan expression by pericytes in pathological microvasculature. Microvasc Res. 2002;63(1):129-134.

114. Reker S, Meier A, Holten-Andersen L, et al. Identification of novel survivin-derived CTL epitopes. Cancer Biol Ther. 2004;3(2):173-179.

115. Siegel S, Wagner A, Friedrichs B, et al. Identification of HLA-A*0201presented $T$ cell epitopes derived from the oncofetal antigen-immature laminin receptor protein in patients with hematological malignancies. J Immunol. 2006;176(11):6935-6944.

116. Zelle-Rieser C, Barsoum AL, Sallusto F, et al. Expression and immunogenicity of oncofetal antigen-immature laminin receptor in human renal cell carcinoma. J Urol. 2001;165(5):1705-1709.

117. Dengjel J, Nastke MD, Gouttefangeas C, et al. Unexpected abundance of HLA class II presented peptides in primary renal cell carcinomas. Clin Cancer Res. 2006;12(14 Pt 1):4163-4170.

118. Takahashi M, Papavero V, Yuhas J, et al. Altered expression of members of the IGF-axis in clear cell renal cell carcinoma. Int J Oncol. 2005;26(4):923-931.

119. Herrem CJ, Tatsumi T, Olson KS, et al. Expression of EphA2 is prognostic of disease-free interval and overall survival in surgically treated patients with renal cell carcinoma. Clin Cancer Res. 2005;11(1):226-231.

120. Van Den Eynde BJ, Gaugler B, Probst-Kepper M, et al. A new antigen recognized by cytolytic $\mathrm{T}$ lymphocytes on a human kidney tumor results from reverse strand transcription. J Exp Med. 1999;190(12):1793-1800.

121. Shomura H, Shichijo S, Matsueda S, et al. Identification of epidermal growth factor receptor-derived peptides immunogenic for HLA-A2(+) cancer patients. Br J Cancer. 2004;90(8):1563-1571. 
122. Sargent ER, Gomella LG, Belldegrun A, Linehan WM, Kasid A. Epidermal growth factor receptor gene expression in normal human kidney and renal cell carcinoma. J Urol. 1989;142(5):1364-1368.

123. Sato E, Torigoe T, Hirohashi $Y$, et al. Identification of an immunogenic CTL epitope of HIFPH3 for immunotherapy of renal cell carcinoma. Clin Cancer Res. 2008;14(21):6916-6923.

124. Schag K, Schmidt SM, Muller MR, et al. Identification of C-met oncogene as a broadly expressed tumor-associated antigen recognized by cytotoxic T-lymphocytes. Clin Cancer Res. 2004;10(11):3658-3666.

125. Campbell CE, Kuriyan NP, Rackley RR, et al. Constitutive expression of the Wilms tumor suppressor gene (WT1) in renal cell carcinoma. Int J Cancer. 1998;78(2):182-188.

126. Oka Y, Udaka K, Tsuboi A, et al. Cancer immunotherapy targeting Wilms' tumor gene WT1 product. J Immunol. 2000;164(4): 1873-1880.

127. Gao L, Bellantuono I, Elsasser A, et al. Selective elimination of leukemic $\mathrm{CD} 34+$ progenitor cells by cytotoxic $\mathrm{T}$ lymphocytes specific for WT1. Blood. 2000;95(7):2198-2203.

128. Ohminami H, Yasukawa M, Fujita S. HLA class I-restricted lysis of leukemia cells by a CD8+ cytotoxic T-lymphocyte clone specific for WT1 peptide. Blood. 2000;95(1):286-293.

129. Muller MR, Grunebach F, Nencioni A, Brossart P. Transfection of dendritic cells with RNA induces CD4- and CD8-mediated T cell immunity against breast carcinomas and reveals the immunodominance of presented T cell epitopes. J Immunol. 2003;170(12):5892-5896.

130. Hiltbold EM, Ciborowski P, Finn OJ. Naturally processed class II epitope from the tumor antigen MUC1 primes human CD4+ T cells. Cancer Res. 1998;58(22):5066-5070.

131. Redchenko I, Harrop R, Ryan MG, Hawkins RE, Carroll MW. Identification of a major histocompatibility complex class I-restricted T-cell epitope in the tumour-associated antigen, 5T4. Immunology. 2006;118(1):50-57.

132. Elkord E, Burt DJ, Drijfhout JW, Hawkins RE, Stern PL. CD4+ T-cell recognition of human 5T4 oncofoetal antigen: implications for initial depletion of CD25+ T cells. Cancer Immunol Immunother. 2008;57(6):833-847.

133. Smyth LJ, Elkord E, Taher TE, et al. CD8 T-cell recognition of human 5T4 oncofetal antigen. Int J Cancer. 2006;119(7):1638-1647.

134. Ronsin C, Chung-Scott V, Poullion I, Aknouche N, Gaudin C, Triebel F. A non-AUG-defined alternative open reading frame of the intestinal carboxyl esterase mRNA generates an epitope recognized by renal cell carcinoma-reactive tumor-infiltrating lymphocytes in situ. J Immunol. 1999;163(1):483-490.

135. Yokoyama Y, Grunebach F, Schmidt SM, et al. Matrilysin (MMP-7) is a novel broadly expressed tumor antigen recognized by antigenspecific T cells. Clin Cancer Res. 2008;14(17):5503-5511.

136. Sumi T, Nakatani T, Yoshida H, et al. Expression of matrix metalloproteinases 7 and 2 in human renal cell carcinoma. Oncol Rep. 2003; 10(3):567-570.

137. Hedberg Y, Davoodi E, Roos G, Ljungberg B, Landberg G. Cyclin-D1 expression in human renal-cell carcinoma. Int J Cancer. 1999; 84(3):268-272.

138. Kondo E, Maecker B, Weihrauch MR, et al. Cyclin D1-specific cytotoxic $\mathrm{T}$ lymphocytes are present in the repertoire of cancer patients: implications for cancer immunotherapy. Clin Cancer Res. 2008; 14(20):6574-6579.

139. Mathieu MG, Linley AJ, Reeder SP, et al. HAGE, a cancer/testis antigen expressed at the protein level in a variety of cancers. Cancer Immun.10:2.

140. Vonderheide RH, Hahn WC, Schultze JL, Nadler LM. The telomerase catalytic subunit is a widely expressed tumor-associated antigen recognized by cytotoxic T lymphocytes. Immunity. 1999;10(6):673-679.

141. Minev B, Hipp J, Firat H, Schmidt JD, Langlade-Demoyen P, Zanetti M. Cytotoxic T cell immunity against telomerase reverse transcriptase in humans. Proc Natl Acad Sci U S A. 2000;97(9): 4796-4801.
142. Schroers R, Shen L, Rollins L, et al. Human telomerase reverse transcriptase-specific T-helper responses induced by promiscuous major histocompatibility complex class II-restricted epitopes. Clin Cancer Res. 2003;9(13):4743-4755.

143. Hanada K, Yewdell JW, Yang JC. Immune recognition of a human renal cancer antigen through post-translational protein splicing. Nature. 2004;427(6971):252-256.

144. Young AC, Craven RA, Cohen D, et al. Analysis of VHL gene alterations and their relationship to clinical parameters in sporadic conventional renal cell carcinoma. Clin Cancer Res. 2009;15(24):7582-7592.

145. Yamanaka K, Miyake H, Hara I, Gohji K, Arakawa S, Kamidono S. Expression of MAGE genes in renal cell carcinoma. Int $J \mathrm{Mol} \mathrm{Med.}$ 1998:2(1):57-60.

146. Kawagoe N, Shintaku I, Yutani S, et al. Expression of the SART3 tumor rejection antigen in renal cell carcinoma. $J$ Urol. 2000;164(6):2090-2095.

147. Mohamed ER, Naito M, Terasaki Y, et al. Capability of SART3 (109-118) peptide to induce cytotoxic T lymphocytes from prostate cancer patients with HLA class I-A11, -A31 and -A33 alleles. Int $J$ Oncol. 2009;34(2):529-536.

148. Minami T, Matsueda S, Takedatsu H, et al. Identification of SART3derived peptides having the potential to induce cancer-reactive cytotoxic T lymphocytes from prostate cancer patients with HLA-A3 supertype alleles. Cancer Immunol Immunother. 2007;56(5):689-698.

149. Ito M, Shichijo S, Miyagi Y, et al. Identification of SART3-derived peptides capable of inducing HLA-A2-restricted and tumor-specific CTLs in cancer patients with different HLA-A2 subtypes. Int J Cancer. 2000;88(4):633-639.

150. Nakao M, Shichijo S, Imaizumi T, et al. Identification of a gene coding for a new squamous cell carcinoma antigen recognized by the CTL. J Immunol. 2000;164(5):2565-2574.

151. Neumann E, Engelsberg A, Decker J, et al. Heterogeneous expression of the tumor-associated antigens RAGE-1, PRAME, and glycoprotein 75 in human renal cell carcinoma: candidates for T-cell-based immunotherapies? Cancer Res. 1998;58(18):4090-4095.

152. Kessler JH, Beekman NJ, Bres-Vloemans SA, et al. Efficient identification of novel HLA-A*0201-presented cytotoxic T lymphocyte epitopes in the widely expressed tumor antigen PRAME by proteasomemediated digestion analysis. $J$ Exp Med. 2001;193(1):73-88.

153. Ikeda $\mathrm{H}$, Lethe $\mathrm{B}$, Lehmann $\mathrm{F}$, et al. Characterization of an antigen that is recognized on a melanoma showing partial HLA loss by CTL expressing an NK inhibitory receptor. Immunity. 1997;6(2):199-208.

154. Kawahara M, Hori T, Matsubara Y, Okawa K, Uchiyama T. Identification of HLA class I-restricted tumor-associated antigens in adult $\mathrm{T}$ cell leukemia cells by mass spectrometric analysis. Exp Hematol. 2006;34(11):1496-1504.

155. Kankuri M, Soderstrom KO, Pelliniemi TT, Vahlberg T, Pyrhonen S, Salminen E. The association of immunoreactive p53 and Ki-67 with T-stage, grade, occurrence of metastases and survival in renal cell carcinoma. Anticancer Res. 2006;26(5B):3825-3833.

156. Chikamatsu K, Nakano K, Storkus WJ, et al. Generation of anti-p53 cytotoxic $\mathrm{T}$ lymphocytes from human peripheral blood using autologous dendritic cells. Clin Cancer Res. 1999;5(6):1281-1288.

157. Oehlrich N, Devitt G, Linnebacher M, et al. Generation of RAGE-1 and MAGE-9 peptide-specific cytotoxic T-lymphocyte lines for transfer in patients with renal cell carcinoma. Int $J$ Cancer. 2005;117(2):256-264.

158. Tatsumi T, Kierstead LS, Ranieri E, et al. MAGE-6 encodes HLADR $\beta 1 * 0401$-presented epitopes recognized by CD4+ T cells from patients with melanoma or renal cell carcinoma. Clin Cancer Res. 2003;9(3):947-954.

159. Kramer BF, Schoor O, Kruger T, et al. MAGED4-expression in renal cell carcinoma and identification of an HLA-A*25-restricted MHC class I ligand from solid tumor tissue. Cancer Biol Ther. 2005;4(9):943-948.

160. Sotiropoulou PA, Perez SA, Iliopoulou EG, et al. Cytotoxic T-cell precursor frequencies to HER-2 ${ }_{369-377}$ in patients with HER-2/neupositive epithelial tumours. Br J Cancer. 2003;89(6):1055-1061. 
161. Sotiropoulou PA, Perez SA, Voelter V, et al. Natural CD8+ T-cell responses against MHC class I epitopes of the HER-2/neu oncoprotein in patients with epithelial tumors. Cancer Immunol Immunother. 2003;52(12):771-779.

162. Ishihara Y, Harada M, Azuma K, et al. HER2/neu-derived peptides recognized by both cellular and humoral immune systems in HLA-A2+ cancer patients. Int J Oncol. 2004;24(4):967-975.

163. Rongcun Y, Salazar-Onfray F, Charo J, et al. Identification of new HER2/neu-derived peptide epitopes that can elicit specific CTL against autologous and allogeneic carcinomas and melanomas. J Immunol. 1999;163(2):1037-1044.

164. Kobayashi H, Wood M, Song Y, Appella E, Celis E. Defining promiscuous MHC class II helper T-cell epitopes for the HER2/neu tumor antigen. Cancer Res. 2000;60(18):5228-5236.

165. Shintaku I, Kawagoe N, Yutani S, et al. Expression of the SART1 tumor rejection antigen in renal cell carcinoma. Urol Res. 2000; 28(3):178-184.

166. Yamada A, Kawano K, Harashima N, et al. Study of HLA class I restriction and the directed antigens of cytotoxic $\mathrm{T}$ lymphocytes at the tumor sites of ovarian cancer. Cancer Immunol Immunother. 1999; 48(2-3):147-152.

167. Kikuchi M, Nakao M, Inoue Y, et al. Identification of a SART-1-derived peptide capable of inducing HLA-A24-restricted and tumor-specific cytotoxic T lymphocytes. Int J Cancer. 1999;81(3):459-466.

168. Gaugler B, Brouwenstijn N, Vantomme V, et al. A new gene coding for an antigen recognized by autologous cytolytic $\mathrm{T}$ lymphocytes on a human renal carcinoma. Immunogenetics. 1996;44(5):323-330.

169. Flad T, Spengler B, Kalbacher H, et al. Direct identification of major histocompatibility complex class I-bound tumor-associated peptide antigens of a renal carcinoma cell line by a novel mass spectrometric method. Cancer Res. 1998;58(24):5803-5811.

170. Touloukian CE, Leitner WW, Robbins PF, et al. Expression of a "self-"antigen by human tumor cells enhances tumor antigen-specific CD4(+) T-cell function. Cancer Res. 2002;62(18):5144-5147.

171. Slingluff CL Jr, Colella TA, Thompson L, et al. Melanomas with concordant loss of multiple melanocytic differentiation proteins: immune escape that may be overcome by targeting unique or undefined antigens. Cancer Immunol Immunother. 2000;48(12):661-672.

172. Wang RF, Robbins PF, Kawakami Y, Kang XQ, Rosenberg SA. Identification of a gene encoding a melanoma tumor antigen recognized by HLA-A31-restricted tumor-infiltrating lymphocytes. $J$ Exp Med. 1995;181(2):799-804.

173. Reckamp KL, Figlin RA, Moldawer N, et al. Expression of CXCR3 on mononuclear cells and CXCR3 ligands in patients with metastatic renal cell carcinoma in response to systemic IL-2 therapy. J Immunother. 2007;30(4):417-424.

174. Margolin KA. Interleukin-2 in the treatment of renal cancer. Semin Oncol. 2000;27(2):194-203.

175. Tatsugami K, Eto M, Naito S. Influence of immunotherapy with interferon-alpha on regulatory $\mathrm{T}$ cells in renal cell carcinoma patients. J Interferon Cytokine Res. 2010;30(1):43-48.

176. Unsinger J, McGlynn M, Kasten KR, et al. IL-7 promotes T cell viability, trafficking, and functionality and improves survival in sepsis. J Immunol. 2010;184(7):3768-3779.

177. Andersson A, Yang SC, Huang M, et al. IL-7 promotes CXCR3 ligand-dependent $\mathrm{T}$ cell antitumor reactivity in lung cancer. J Immunol. 2009;182(11):6951-6958.

178. Bayer AL, Lee JY, de la Barrera A, Surh CD, Malek TR. A function for IL-7R for CD4+CD25+Foxp3+ T regulatory cells. J Immunol. 2008;181(1):225-234.

179. Ogawa M, Tsutsui T, Zou JP, et al. Enhanced induction of very late antigen 4/lymphocyte function-associated antigen 1-dependent T-cell migration to tumor sites following administration of interleukin 12 . Cancer Res. 1997;57(11):2216-2222.

180. Trinchieri G, Pflanz S, Kastelein RA. The IL-12 family of heterodimeric cytokines: new players in the regulation of $\mathrm{T}$ cell responses. Immunity. 2003;19(5):641-644.
181. Indrova M, Bieblova J, Bubenik J, Reinis M. IL-12 immunotherapy of minimal residual disease in murine models of HPV16-associated tumours: induction of immune responses, cytokine production and kinetics of immune cell subsets. Int J Oncol. 2008;32(2): 499-507.

182. Basak GW, Zapala L, Wysocki PJ, Mackiewicz A, Jakobisiak M, Lasek W. Interleukin 15 augments antitumor activity of cytokine gene-modified melanoma cell vaccines in a murine model. Oncol Rep. 2008;19(5):1173-1179.

183. Vang KB, Yang J, Mahmud SA, Burchill MA, Vegoe AL, Farrar MA. IL-2, -7 , and -15 , but not thymic stromal lymphopoeitin, redundantly govern CD4+Foxp3+ regulatory T cell development. J Immunol. 2008; 181(5):3285-3290.

184. Coughlin CM, Salhany KE, Wysocka M, et al. Interleukin-12 and interleukin-18 synergistically induce murine tumor regression which involves inhibition of angiogenesis. J Clin Invest. 1998; 101(6): 1441-1452.

185. Robertson MJ, Kirkwood JM, Logan TF, et al. A dose-escalation study of recombinant human interleukin-18 using two different schedules of administration in patients with cancer. Clin Cancer Res. 2008;14(11):3462-3469.

186. Carroll RG, Carpenito C, Shan X, et al. Distinct effects of IL-18 on the engraftment and function of human effector CD8 T cells and regulatory T cells. PLoS One. 2008;3(9):e3289.

187. Casey KA, Mescher MF. IL-21 promotes differentiation of naive CD8 $\mathrm{T}$ cells to a unique effector phenotype. J Immunol. 2007;178(12):7640-7648.

188. Ebert EC. Interleukin 21 up-regulates perforin-mediated cytotoxic activity of human intra-epithelial lymphocytes. Immunology. 2009;127(2):206-215.

189. Moroz A, Eppolito C, Li Q, Tao J, Clegg CH, Shrikant PA. IL-21 enhances and sustains CD8+ T cell responses to achieve durable tumor immunity: comparative evaluation of IL-2, IL-15, and IL-21. J Immunol. 2004;173(2):900-909.

190. Wuest TY, Willette-Brown J, Durum SK, Hurwitz AA. The influence of IL-2 family cytokines on activation and function of naturally occurring regulatory T cells. J Leukoc Biol. 2008;84(4):973-980.

191. Cho HJ, Hayashi T, Datta SK, et al. IFN-alpha beta promote priming of antigen-specific CD8+ and CD4+ T lymphocytes by immunostimulatory DNA-based vaccines. J Immunol. 2002;168(10): 4907-4913.

192. Sikora AG, Jaffarzad N, Hailemichael Y, et al. IFN-alpha enhances peptide vaccine-induced $\mathrm{CD} 8+\mathrm{T}$ cell numbers, effector function, and antitumor activity. J Immunol. 2009;182(12):7398-7407.

193. Mohty AM, Grob JJ, Mohty M, Richard MA, Olive D, Gaugler B. Induction of IP-10/CXCL10 secretion as an immunomodulatory effect of low-dose adjuvant interferon-alpha during treatment of melanoma. Immunobiology. 2010;215(2):113-123.

194. Ogasawara K, Hida S, Weng Y, et al. Requirement of the IFN-alpha/ beta-induced CXCR3 chemokine signalling for CD8+ T cell activation. Genes Cells. 2002;7(3):309-320.

195. Stewart TJ, Greeneltch KM, Reid JE, et al. Interferon regulatory factor- 8 modulates the development of tumor-induced CD11 $\mathrm{b}^{+} \mathrm{Gr}-1^{+}$ myeloid cells. J Cell Mol Med. 2009;13(9B):3939-3950.

196. Kelchtermans H, De Klerck B, Mitera T, et al. Defective CD4+CD25+ regulatory $\mathrm{T}$ cell functioning in collagen-induced arthritis: an important factor in pathogenesis, counter-regulated by endogenous IFNgamma. Arthritis Res Ther. 2005;7(2):R402-R415.

197. Sercan O, Stoycheva D, Hammerling GJ, Arnold B, Schuler T. IFN-gamma receptor signaling regulates memory CD8+ T cell differentiation. J Immunol. 2010;184(6):2855-2862.

198. Jager E, Ringhoffer M, Dienes HP, et al. Granulocyte-macrophagecolony-stimulating factor enhances immune responses to melanomaassociated peptides in vivo. Int J Cancer. 1996;67(1):54-62.

199. Kared H, Leforban B, Montandon R, et al. Role of GM-CSF in tolerance induction by mobilized hematopoietic progenitors. Blood. 2008;112(6):2575-2578. 
200. Morales JK, Kmieciak M, Knutson KL, Bear HD, Manjili MH. GM-CSF is one of the main breast tumor-derived soluble factors involved in the differentiation of CD11b-Gr1- bone marrow progenitor cells into myeloid-derived suppressor cells. Breast Cancer Res Treat. 2009. [Epub ahead of print Nov 24].

201. Tani K, Azuma M, Nakazaki Y, et al. Phase I study of autologous tumor vaccines transduced with the GM-CSF gene in four patients with stage IV renal cell cancer in Japan: clinical and immunological findings. Mol Ther. 2004;10(4):799-816.

202. Na IK, Keilholz U, Letsch A, et al. Addition of GM-CSF to a peptide/KLH vaccine results in increased frequencies of CXCR3expressing $\mathrm{KLH}$-specific T cells. Cancer Immunol Immunother. 2007;56(3):391-396.

203. Rowe JH, Johanns TM, Ertelt JM, Lai JC, Way SS. Cytotoxic T-lymphocyte antigen 4 blockade augments the T-cell response primed by attenuated Listeria monocytogenes resulting in more rapid clearance of virulent bacterial challenge. Immunology. 2009;128 (1 Suppl):e471-e478.

204. Peggs KS, Quezada SA, Chambers CA, Korman AJ, Allison JP. Blockade of CTLA-4 on both effector and regulatory T cell compartments contributes to the antitumor activity of anti-CTLA-4 antibodies. J Exp Med. 2009;206(8):1717-1725.

205. Tuyaerts S, Van Meirvenne S, Bonehill A, et al. Expression of human GITRL on myeloid dendritic cells enhances their immunostimulatory function but does not abrogate the suppressive effect of CD4+CD25+ regulatory T cells. J Leukoc Biol. 2007;82(1):93-105.

206. Bushell A, Wood K. GITR ligation blocks allograft protection by induced $\mathrm{CD} 25+\mathrm{CD} 4+$ regulatory $\mathrm{T}$ cells without enhancing effector T-cell function. Am J Transplant. 2007;7(4):759-768.

207. Cohen AD, Diab A, Perales MA, et al. Agonist anti-GITR antibody enhances vaccine-induced CD8(+) T-cell responses and tumor immunity. Cancer Res. 2006;66(9):4904-4912.

208. Wells JW, Cowled CJ, Farzaneh F, Noble A. Combined triggering of dendritic cell receptors results in synergistic activation and potent cytotoxic immunity. J Immunol. 2008;181(5):3422-3431.

209. Mackey MF, Barth RJ Jr, Noelle RJ. The role of CD40/CD154 interactions in the priming, differentiation, and effector function of helper and cytotoxic T cells. J Leukoc Biol. 1998;63(4):418-428.

210. Ryan CM, Staveley-O'Carroll K, Schell TD. Combined anti-CD40 conditioning and well-timed immunization prolongs CD8+ T cell accumulation and control of established brain tumors. J Immunother. 2008;31(9):906-920.

211. Pan PY, Ma G, Weber KJ, et al. Immune stimulatory receptor CD40 is required for T-cell suppression and $\mathrm{T}$ regulatory cell activation mediated by myeloid-derived suppressor cells in cancer. Cancer Res. 2010;70(1):99-108.

212. Wang W, Lau R, Yu D, Zhu W, Korman A, Weber J. PD1 blockade reverses the suppression of melanoma antigen-specific CTL by CD4+ CD25(Hi) regulatory T cells. Int Immunol. 2009;21(9):1065-1077.

213. Keir ME, Freeman GJ, Sharpe AH. PD-1 regulates self-reactive CD8+ $\mathrm{T}$ cell responses to antigen in lymph nodes and tissues. J Immunol. 2007;179(8):5064-5070.

214. Bansal-Pakala P, Halteman BS, Cheng MH, Croft M. Costimulation of CD8 T cell responses by OX40. J Immunol. 2004;172(8): $4821-4825$.

215. Ruby CE, Yates MA, Hirschhorn-Cymerman D, et al. Cutting edge: OX40 agonists can drive regulatory $\mathrm{T}$ cell expansion if the cytokine milieu is right. J Immunol. 2009;183(8):4853-4857.

216. Gough MJ, Ruby CE, Redmond WL, Dhungel B, Brown A, Weinberg AD. OX40 agonist therapy enhances CD8 infiltration and decreases immune suppression in the tumor. Cancer Res. 2008;68(13):5206-5215.

217. Morris A, Vetto JT, Ramstad T, et al. Induction of anti-mammary cancer immunity by engaging the OX-40 receptor in vivo. Breast Cancer Res Treat. 2001;67(1):71-80.

218. Piconese S, Valzasina B, Colombo MP. OX40 triggering blocks suppression by regulatory $\mathrm{T}$ cells and facilitates tumor rejection. $J$ Exp Med. 2008;205(4):825-839.
219. Redmond WL, Gough MJ, Charbonneau B, Ratliff TL, Weinberg AD. Defects in the acquisition of CD8 $\mathrm{T}$ cell effector function after priming with tumor or soluble antigen can be overcome by the addition of an OX40 agonist. J Immunol. 2007;179(11):7244-7253.

220. Myers L, Lee SW, Rossi RJ, et al. Combined CD137 (4-1BB) and adjuvant therapy generates a developing pool of peptide-specific CD8 memory T cells. Int Immunol. 2006;18(2):325-333.

221. Lee HW, Park SJ, Choi BK, Kim HH, Nam KO, Kwon BS. 4-1BB promotes the survival of $\mathrm{CD} 8+\mathrm{T}$ lymphocytes by increasing expression of Bcl-xL and Bfl-1. J Immunol. 2002;169(9):4882-4888.

222. Ju SA, Lee SC, Kwon TH, et al. Immunity to melanoma mediated by 4-1BB is associated with enhanced activity of tumour-infiltrating lymphocytes. Immunol Cell Biol. 2005;83(4):344-351.

223. Laderach D, Movassagh M, Johnson A, Mittler RS, Galy A. 4-1BB co-stimulation enhances human CD8+ T cell priming by augmenting the proliferation and survival of effector $\mathrm{CD} 8+\mathrm{T}$ cells. Int Immunol. 2002;14(10):1155-1167.

224. Liu S, Breiter DR, Zheng G, Chen A. Enhanced antitumor responses elicited by combinatorial protein transfer of chemotactic and costimulatory molecules. J Immunol. 2007;178(5):3301-3306.

225. Shackleton M, Davis ID, Hopkins W, et al. The impact of imiquimod, a toll-like receptor-7 ligand (TLR7L), on the immunogenicity of melanoma peptide vaccination with adjuvant Flt3 ligand. Cancer Immun. 2004;4:9.

226. Barnetson RS, Satchell A, Zhuang L, Slade HB, Halliday GM. Imiquimod induced regression of clinically diagnosed superficial basal cell carcinoma is associated with early infiltration by CD4 T cells and dendritic cells. Clin Exp Dermatol. 2004;29(6): 639-643.

227. Warger T, Rechtsteiner G, Schmid B, Osterloh P, Schild H, Radsak MP. Transcutaneous immunization with imiquimod is amplified by CD40 ligation and results in sustained cytotoxic T-lymphocyte activation and tumor protection. Clin Rev Allergy Immunol. 2007;32(1): $57-66$.

228. Wille-Reece U, Wu CY, Flynn BJ, Kedl RM, Seder RA. Immunization with HIV-1 Gag protein conjugated to a TLR7/8 agonist results in the generation of HIV-1 Gag-specific Th1 and CD8+ T cell responses. J Immunol. 2005;174(12):7676-7683.

229. Lehner M, Morhart P, Stilper A, et al. Efficient chemokine-dependent migration and primary and secondary IL-12 secretion by human dendritic cells stimulated through Toll-like receptors. J Immunother. 2007;30(3):312-322.

230. Urry Z, Xystrakis E, Richards DF, et al. Ligation of TLR9 induced on human IL-10-secreting tregs by 1alpha,25-dihydroxyvitamin D3 abrogates regulatory function. J Clin Invest. 2009;119(2): 387-398.

231. de Alencar BC, Araujo AF, Penido ML, Gazzinelli RT, Rodrigues MM. Cross-priming of long lived protective CD8+ T cells against Trypanosoma cruzi infection: importance of a TLR9 agonist and CD4+ T cells. Vaccine. 2007;25(32):6018-6027.

232. Haining WN, Davies J, Kanzler H, et al. CpG oligodeoxynucleotides alter lymphocyte and dendritic cell trafficking in humans. Clin Cancer Res. 2008;14(17):5626-5634.

233. Fricke I, Mirza N, Dupont J, et al. Vascular endothelial growth factortrap overcomes defects in dendritic cell differentiation but does not improve antigen-specific immune responses. Clin Cancer Res. 2007;13(16):4840-4848.

234. Ko JS, Bukowski RM, Fincke JH. Myeloid-derived suppressor cells: a novel therapeutic target. Curr Oncol Rep. 2009;11(2):87-93.

235. Houben R, Voigt H, Noelke C, Hofmeister V, Becker JC, Schrama D. MAPK-independent impairment of T-cell responses by the multikinase inhibitor sorafenib. Mol Cancer Ther. 2009;8(2):433-440.

236. Osada T, Chong G, Tansik R, et al. The effect of anti-VEGF therapy on immature myeloid cell and dendritic cells in cancer patients. Cancer Immunol Immunother. 2008;57(8):1115-1124.

237. Bellati F, Napoletano C, Ruscito I, et al. Complete remission of ovarian cancer induced intractable malignant ascites with intraperitoneal bevacizumab. Immunological observations and a literature review. Invest New Drugs. 2009. [Epub ahead of print Nov 24]. 
238. Dawson NA, Guo C, Zak R, et al. A phase II trial of gefitinib (Iressa, ZD1839) in stage IV and recurrent renal cell carcinoma. Clin Cancer Res. 2004;10(23):7812-7819.

239. Jermann M, Stahel RA, Salzberg M, et al. A phase II, open-label study of gefitinib (IRESSA) in patients with locally advanced, metastatic, or relapsed renal-cell carcinoma. Cancer Chemother Pharmacol. 2006;57(4):533-539.

240. Andrade Filho PA, Lopez-Albaitero A, Gooding W, Ferris RL. Novel immunogenic HLA-A*0201-restricted epidermal growth factor receptor-specific T-cell epitope in head and neck cancer patients. J Immunother. 2010;33(1):83-91.

241. Metzler B, Gfeller P, Wieczorek G, Katopodis A. Differential promotion of hematopoietic chimerism and inhibition of alloreactive $\mathrm{T}$ cell proliferation by combinations of anti-CD40Ligand, anti-LFA-1, everolimus, and deoxyspergualin. Transpl Immunol. 2008;20(1-2):106-112.

242. Hsu FJ, Komarovskaya M. CTLA4 blockade maximizes antitumor T-cell activation by dendritic cells presenting idiotype protein or opsonized anti-CD20 antibody-coated lymphoma cells. J Immunother. 2002;25(6):455-468.

243. Quezada SA, Peggs KS, Curran MA, Allison JP. CTLA4 blockade and GM-CSF combination immunotherapy alters the intratumor balance of effector and regulatory $\mathrm{T}$ cells. J Clin Invest. 2006;116(7):1935-1945.

244. Morse MA, Hobeika AC, Osada T, et al. Depletion of human regulatory $\mathrm{T}$ cells specifically enhances antigen-specific immune responses to cancer vaccines. Blood. 2008;112(3):610-618.
245. Petrausch U, Jensen SM, Twitty C, et al. Disruption of TGF-beta signaling prevents the generation of tumor-sensitized regulatory $\mathrm{T}$ cells and facilitates therapeutic antitumor immunity. J Immunol. 2009;183(6):3682-3689.

246. Sanjabi S, Mosaheb MM, Flavell RA. Opposing effects of TGF-beta and IL-15 cytokines control the number of short-lived effector CD8+ T cells. Immunity. 2009;31(1):131-144.

247. Kim S, Buchlis G, Fridlender ZG, et al. Systemic blockade of transforming growth factor-beta signaling augments the efficacy of immunogene therapy. Cancer Res. 2008;68(24):10247-10256.

248. Castro AG, Neighbors M, Hurst SD, et al. Anti-interleukin 10 receptor monoclonal antibody is an adjuvant for T helper cell type 1 responses to soluble antigen only in the presence of lipopolysaccharide. $J$ Exp Med. 2000;192(10):1529-1534.

249. Chen G, Liu J, Wang QH, et al. Effects of CD4(+)CD25(+)Foxp3(+) regulatory $\mathrm{T}$ cells on early Plasmodium yoelii $17 \mathrm{XL}$ infection in BALB/c mice. Parasitology. 2009;136(10):1107-1120.

250. Collison LW, Workman CJ, Kuo TT, et al. The inhibitory cytokine IL-35 contributes to regulatory T-cell function. Nature. 2007;450(7169):566-569.

251. Ou X, Cai S, Liu P, et al. Enhancement of dendritic cell-tumor fusion vaccine potency by indoleamine-pyrrole 2,3-dioxygenase inhibitor, 1-MT. J Cancer Res Clin Oncol. 2008;134(5):525-533.
Open Access Journal of Urology

\section{Publish your work in this journal}

The Open Access Journal of Urology is an international, peer-reviewed, open access journal publishing original research, reports, editorials, reviews and commentaries on all aspects of adult and pediatric urology in the clinic and laboratory including the following topics: Pathology, pathophysiology of urological disease; Investigation and treatment of

\section{Dovepress}

urological disease; Pharmacology of drugs used for the treatment of urological disease. The manuscript management system is completely online and includes a very quick and fair peer-review system, which is all easy to use. Visit http://www.dovepress.com/testimonials.php to read real quotes from published authors. 